\title{
Ideas Have Consequences: The Impact of Law and Economics on American Justice
}

\section{Working Paper}

\section{Author(s):}

Ash, Elliott; Chen, Daniel L.; Naidu, Suresh

Publication date:

2019-03

Permanent link:

https://doi.org/10.3929/ethz-b-000376884

Rights / license:

In Copyright - Non-Commercial Use Permitted

Originally published in:

Center for Law \& Economics Working Paper Series 04/2019 


\section{GHzürich}

\section{Center for Law \& Economics Working Paper Series}

Number 04/2019

Ideas Have Consequences: The Impact of Law and Economics on American Justice

Elliott Ash

Daniel L. Chen

Suresh Naidu 


\title{
Ideas Have Consequences: The Impact of Law and Economics on American Justice
}

\author{
Elliott Ash, Daniel L. Chen, Suresh Naidu*
}

March 20, 2019

\section{Preliminary and Incomplete Version: Comments Welcome.}

\begin{abstract}
This paper provides a quantitative analysis of the effects of the early law and economics movement on the U.S. judiciary. Using the universe of published opinions in U.S. Circuit Courts and 1 million District Court criminal sentencing decisions linked to judge identity, we estimate the effect of attendance in the controversial Manne economics training program, an intensive course attended by almost half of federal judges between 1976 and 1999. After attending economics training, participating judges use more economics language, render more conservative verdicts in economics cases, rule against regulatory/taxation agencies more often, and impose longer criminal sentences. These results are robust to adjusting for a wide variety of covariates that predict the timing of attendance. Non-Manne judges randomly exposed to Manne peers on previous cases increase their use of economics language in subsequent opinions, suggesting economics ideas diffused throughout the judiciary.
\end{abstract}

Keywords: Judicial Decision-Making, Ideology, Intellectual History.

JEL codes: D7, K0, Z1.

*Elliott Ash, ashe@ethz.ch, ETH Zurich; Daniel L. Chen, daniel.chen@iast.fr, Toulouse School of Economics, Institute for Advanced Study in Toulouse, University of Toulouse Capitole, Toulouse, France; Suresh Naidu, sn2430@columbia.edu, Columbia University, Economics Department/SIPA. First draft: July 2016. Current draft: March 2019. Latest version at nber.org/ dlchen/papers/ Ideas_Have_Consequences.pdf Work on this project was conducted while Chen received financial support from the European Research Council (Grant No. 614708), Swiss National Science Foundation (Grant Nos. 100018-152678 and 106014-150820), and Agence Nationale de la Recherche. Thanks to Jesus Rodriguez, Wei Lu, Jacopo Bregolin, Grace Zhang, Jeff Jacobs, Lorenzo Lagos, Zoey Chopra, and Yutong Li for helpful research assistance. We thank Henry Butler, Jeremy Kessler, Ilyana Kuziemko, Henry Farrell, Eric Posner, and numerous seminar participants for helpful comments and conversations. We thank Joshua Fischman and Gregory Conko for information on judge attendance from the GMU LEC. 


\section{Introduction}

U.S. federal judges interpret and apply the law and make legal precedent under significant uncertainty. This subjective decision-making creates scope for schools of thinking, defined as a system of ideas and normative commitments which form basis for policy. A school of thought may help a judge pay attention to salient features, not unlike heuristics we use to focus on salient product attributes when making decisions (Köszegi and Szeidl 2013). These decisions need not be rational, either, as a large literature has documented the role of salience in judicial decision making (Bordalo et al. 2015), ${ }^{1}$ creating a role for a set of heuristics or principles of thinking that agents use to organize their values (Falk and Tirole 2016).

This paper aims to quantify the impact on judging of a novel and actively promoted legal theory - law and economics - which emphasizes deterrence and cost-benefit utilitarian analysis. We use the variation in exposure to law and economics induced by the Manne Economics Institute for Federal Judges, an economics training course aimed at the federal judiciary, together with the institutional structure of the U.S. federal courts, to generate quasi-experimental variation.

The setting we examine is extremely relevant for policy. American law makes giants of its judges. The U.S. federal courts (the 13 Circuit Courts and 94 District Courts) operate in an incremental common law space - continually finding new rules and legal distinctions that future cases must follow (Gennaioli and Shleifer 2007). Random assignment of judges to cases (to panels of 3 in Circuit Courts) controls for court- and case-level factors. ${ }^{2}$ These judges (numbering roughly 180 in circuit courts and 680 in district courts) are appointed by the president and serve with life tenure. These courts handle hundreds of thousands of cases per year (roughly 67,000 in circuit courts and 330,000 in district courts), while the Supreme Court hears only 100 cases per year. Relatively few district court cases make it to the circuits, while more than 99 percent of Circuit decisions are final. Therefore they comprise the vast majority of what law students are reading.

This paper utilizes a dataset on all 380,000 cases (over a million judge votes) in Circuit Courts for 1891-2013, and a data set on one million criminal sentencing decisions

\footnotetext{
${ }^{1}$ Before Presidential elections, U.S. Courts of Appeals judges are twice as likely to dissent, vote, and make precedent along partisan lines (Berdejo and Chen 2016; Chen 2016). Mood, gambler's fallacy, and voice seem to affect judicial decisions (Chen 2014; Chen et al. 2016; Chen et al. 2015).

${ }^{2}$ This randomness has been used in a growing set of economics papers (Kling 2006; Maestas et al. 2013; Belloni et al. 2012; Dahl et al. 2014; Mueller-Smith 2014; Ash and Chen 2017).
} 
in U.S. District Courts linked to judge identity (via FOIA request) for 1992-2011. We have detailed information on the judges and the metadata associated with the cases. In addition, we process the text of the written opinions to represent judge writing as a vector of phrase frequencies.

To identify the impact of law and economics training on judicial outcomes, we exploit judicial attendance in the Manne program, a controversial economics training program for federal judges funded by business and conservative foundations. We estimate the impact on decisions and language in a differences-in-differences framework. We take care to check for pre-trends in the outcome variable. Our results hold conditional on a rich set of judicial characteristics, interacted with treatment and time, which would otherwise predict the timing of attendance.

To measure the influence of law and economics, we compute textual distance between written opinions and a corpus of academic law and economics articles, and trace the spread of economic ideas in the courts and impacts on the population. We find that judges significantly increase their use of economics language after attending the Manne program. Using the $5 \%$ sample of hand-coded cases produced by Songer and Auburn (see, e.g., Haire et al. (2003)) we find that, post Manne attendance, judges render conservative verdicts in economics-relevant cases. Further, using the $100 \%$ sample of machine-coded circuit cases, we find that Manne attendees subsequently are more likely to rule against regulatory agencies, in particular the EPA and NLRB. They are also more likely to rule in favor of taxpayers against the Internal Revenue Service.

Next we look at criminal sentencing in the district courts. We find that Manne attendance is associated with harsher prison sentences imposed. We show that the difference in sentencing harshness between Manne and non-Manne judges is highest after the 2005 Booker decision gave more discretion to judges in sentencing. We find that Manne attendance is associated with disparate sentencing. The results are consistent with judges learning a theories of simple deterrence and the use of stereotypes as being economically efficient (see, e.g., Bordalo et al. 2016; Cover and Thomas 1991)-that discrimination in prices and in punishment can be analyzed in terms of economic efficiency, which syllabi obtained from Manne program archives explicitly covered.

The influence of law and economics went beyond the judges that attended the Manne program. Exploiting random panel composition, we document extensive spillovers consistent with both peer and learning effects. Having an economics trained judge on the authoring judge's previous panel impacts the decision. There is no effect in a set of placebo cases (whether a Manne judge sits on the judge's next panel, whether a Manne 
judge sits on the court's previous case, and whether the Manne co-panelist had not yet received the training). There are spillovers on rulings against regulatory agencies.

Finally, we look at the possibility of general economic reasoning diffusing across domains of the law. We exploit the fact that the topic of a case is also random, and so some judges will be paired with a Manne judge when deciding a pure "economics" case, such as regulation, and then will subsequently face a case from a topic without obvious economic content, like a criminal case. With this approach we are able to test for the "portability" of economic ideas across legal contexts, within the same judge. We find that sitting with a Manne judge increases the use of "deterrence" in a non-Manne judge's own subsequent opinions (and not in the placebo cases). We see that phrases like "deterrence", "capital", and "law and economics" tend to cross topic boundaries within a judge. In particular, economic concepts travel from regulatory cases to criminal cases, but not vice versa. Analyzing these multiple channels of diffusion is possible thanks to the unique structure of the U.S. federal court system, which generates random variation in exposure to ideas.

Our paper is closely related to four literatures. The first is one in experimental economics studying the link between economics training and social preferences. Economics students are less redistributive of potential lottery winnings (Selten and Ockenfels 1998). They favor profit maximization in business vignettes (Rubinstein 2006). They view surge prices more fairly and even beginning economics students hold different views (Frey et al. 2003). Economics professors are less ideologically liberal and less likely to be registered Democrats (or contribute to Democratic candidates) than the other social sciences(Jelveh et al. 2014).

The second literature examines the effects of economics education on political ideology. The closest paper is Fisman et al. (2009), which used random assignment of law students to law professors to look at whether exposure to a professor with an economics $\mathrm{PhD}$ (as opposed to no PhD, or a PhD in Philosophy or History) has an impact on social preferences. The paper found that students with economics exposure behaved less pro-socially in lab experiments 1 and 3 years later, and suggests a potential mechanism for what Karl Polanyi (1944) might call "the great transformation" of American law, in which economic reasoning replaced older, less-market-orented, considerations (Harcourt 2011). A more recent paper, Cantoni et al. (2014), analyzes a staggered Chinese curricular reform which caused students (as intended) to be more skeptical of free markets. Alesina and Fuchs-Schündeln (2007) show that after reunification, East German individuals had persistently higher preferences for government intervention and 
redistribution than West German individuals .3 Our paper differs from these papers, as well as others that are more qualitative (Hirschman 1978, 1991), in that we look at real-world high-stakes decisions rather than decisions in lab games or survey responses.

The third literature we relate to is a burgeoning one on text-as-data and narrative economics (Gentzkow et al., 2017a). Jelveh et al. (2015) classified economic text as conservative or liberal using the political donations of authors; one related finding to this work is that Journal of Law and Economics consistently ranks as right-wing. Ash (2016) finds that the words in the tax code are as important for partisan tax policy as marginal rates. Related work on congressional speech includes Jensen et al. (2012), Ash et al. (2017), and Gentzkow et al. (2017b), who provide an economic interpretation of language as a discrete choice model. Our innovation in this literature is the the random assignment of judges to documents, the use of an auxiliary corpus for classifying language, and the analysis of language diffusion using random exposure to ideologically treated judges. Previous textual measures have had to rely on selection on observables, at best, to address selective mapping of authors to topics or types of text. The random assignment of judges to cases allows us to obtain a relatively clean estimate of author effects independent of topic. ${ }^{4}$

The fourth related literature is on constitutional constraints to policymaking (Besley and Coate 1997; Seabright 1996) and the importance of ideas versus institutions in determining policy (Rodrik 2014, Romer 2002). Judges vary widely in their approach to law and decisions are correlated with characteristics (Stephenson 2009; Ash and MacLeod 2015). But an open question is whether the judges are per se biased for particular outcomes, as opposed to following different legal philosophies (Posner 1973; Cameron 1993; Kornhauser 1999). For example, a judge might in principle employ a strict interpretation of the Constitution, while not necessarily hewing to the preferences of political parties for specific outcomes. Quantifying the role for legal philosophy such as law and economics - is a key contribution of this paper.

The remainder of the paper is organized as follows. Section 2 gives background on the law and economics movement and the Manne program. Section 3 explains our various sources of data and measurement strategies. Section 4 examines the impact of economics-trained judges on a variety of judicial decision making margins. Section 5 examines the impact of peer economics training, exploiting random assignment of peers

\footnotetext{
${ }^{3}$ Fuchs-Schündeln and Masella (2016) examines the impact of socialist education.

${ }^{4}$ We also contribute to a large legal scholarship that conducts textual analysis including but not limited to the question--"Do judge writing styles matter?"- raised by Judge Richard Posner (1995).
} 
on judicial panels. Section 6 concludes.

\section{The Law and Economics Movement}

\section{$2.1 \quad$ Background}

To fix ideas, three canonical examples from contracts, torts, and criminal law illustrate the potential impact of economic thinking. In contracts law, what used to be a general duty to keep promises became "efficient breach theory". This is the idea that if two parties are in a contract, one should be allowed to walk away, so long as it is economically efficient to do so, an idea articulated in a 1977 law review article by Goetz and Scott (1977) that Richard Posner made into law in 1985 in Lake River Corp. v. Carborundum Co. (7th Cir. 1985). In accident law, the duty of care can be defined economically, when the probability of loss times the size of the loss exceeds the cost of taking precautions. The principle underlying this is one of a least cost avoider (Calabresi, 1970)-is it less costly for you to take precautions than it is for the accident to happen to me in expectation? This principle can also carry into criminal law, where the probability of detection times the size of the sanction yields the expected sanction. If a judge approaches a decision thinking that the cost of detection is high relative to the cost of sanctions, which may seem a mark on a paper, the judge may increase the sanctions if the judge approaches the decision as a social planner. As Richard Posner states:

"I pay very little attention to legal rules, statutes, constitutional provisions ... The first thing you do is ask yourself — forget about the law what is a sensible resolution of this dispute? ... See if a recent Supreme Court precedent or some other legal obstacle stood in the way of ruling in favor of that sensible resolution. ... When you have a Supreme Court case or something similar, they're often extremely easy to get around." (An Exit Interview with Richard Posner, New York Times, Sep. 11, 2017).

The increase in the use of economics in law over the past half-century is well-known (see Teles (2012) for a history). Economics has been influential in all areas of law (Posner 1987), advancing the application of economic principles to jurisprudence and prioritizing economic efficiency — as both a positive determinant of past jurisprudence (such as evolution of common law) and a normative goal of future case law (such as 
how to make judicial decisions). Ellickson (2000) documents that law and economics has also grown in importance in legal scholarship.

Law and economics' key criticism of regulatory policies is that they have perverse, unintended economic consequences. In the domain of labor regulation, law and economics scholars (and judges) wrote extensively against New Deal labor law and union protections (Epstein, 1983; Posner, 1984). In EPA regulation, almost all environmental regulations can be construed as a form of government expropriation that limits how property owners can develop their property (Blumm, 1995).

Reliance on economic analysis in antitrust has attained nearly complete consensus (Ginsburg 2010). By the 1960s, the Supreme Court had read into previous statutes a variety of anti-competitive social and political goals, such as protecting small traders from their larger and more efficient rivals as well as curbing inequality in the distribution of income and undue influence of large business. The law-and-economics movement advanced the initially controversial view that the antitrust laws should promote economic efficiency and consumer welfare, rather than shield individuals from competitive market forces or redistribute income across groups of consumers. In the recent time period, judges who attended law-and-economics training were less likely to have their antitrust decisions appealed (Baye and Wright 2011).

A more controversial branch of law and economics is the use of incentives reasoning in criminal law. In Becker's (1968) analysis of crime and punishment, the notion of "rational criminals" works against the then-prevailing wisdom of crime as a product of mental illness. This change in perspective motivates deterrence (more police, more punishment) rather than rehabilitation (more social services and mental health treatment) as the preferred focus of crime policy. Today, the focus is on legitimacy-that individuals may follow the law irrespective of the probability of sanction (Tyler 2002). The theory of optimal deterrence laid out by Becker suggests that severity of punishment can make up for certainty of sanction. ${ }^{5}$ Raising certainty of detection (more policing) is socially costly, while severity of punishment is relatively cheap. ${ }^{6}$ While cash fines are preferred

\footnotetext{
${ }^{5}$ To quote Becker (pg 17): "an increased probability of conviction obviously absorbs public and private resources in the form of more policemen, judges, juries, and so forth. Consequently, a 'compensated' reduction in this probability obviously reduces expenditures on combating crime, and, since the expected punishment is unchanged, there is no 'obvious' offsetting increase in either the amount of damages or the cost of punishments. The result can easily be continuous political pressure to keep police and other expenditures relatively low and to compensate by meting out strong punishments to those convicted."

${ }^{6}$ The idea of least cost avoidance also underlies expected deterrence in criminal law. A rational potential criminal calculates the probability of detection times the sanction to get the expected sanction.
} 
over punishments, many criminal agents are liquidity-constrained and therefore additional punishments are required (pg 31). Arguably, deterrence theory has provided

some justification for the massive build-up of prisons since the $1980 \mathrm{~s} .{ }^{7}$ Most recently, there has been a move toward a more nuanced view of how deterrence operates in parallel to the behavioral economics revolution: e.g., swiftness, certainty, and fairness might make a much bigger impact in deterring criminal behavior than severity (Kleiman 2009; Nagin 1998; van Winden and Ash 2012).

Not surprisingly, given its effects on labor, environmental, antitrust, and criminal law, to name but a few, law and economics is perceived as ideologically conservative by historians. Teles (2012) provides a detailed history of the conservative legal movement, and the role of law and economics. The Law and Economics Center, influential in the judiciary and academia, is well-funded by conservative business interests.

\subsection{The Manne Economic Institute for Federal Judges}

The influence of economics on legal thought is, in part, due to a controversial economics training program for sitting judges, the Economics Institute for Federal Judges. The program was founded in 1976 as a 2-3 week economics course for federal judges. The center began at the University of Miami in 1974, then moved to Emory University, prior to its current location at George Mason University. The course was founded and organized by Henry Manne, an influential conservative in the early law and economics movement. The institute was the the flagship program of the Law and Economics Center, the first academic research center devoted to law and economics. It was funded mainly by donations from conservative foundations and business interests. ${ }^{8}$

An excellent summary of the program is provided by Butler (1999), written by a former director. The course ran continuously, with courses running once or twice a

A judge who follows least cost avoider theory might perceive the cost of detection as high, but the cost of sanction as low, so might increase sanctions if approaching the decision as a social planner.

${ }^{7}$ With a boomlet for community policing in the 1990s, deterrence has remained central. Generally, rehabilitation and retribution are out of favor (Martinson 1974; Petersilia and Turner 1993; Cullen and Gendreau 2001), and deterrence is viewed as the dominant purpose of criminal justice. Harcourt (2011) suggests that this emphasis on deterrence and increased punitiveness is complementary to laissez-faire economic ideology. By deterring non-market opportunism, criminal law incentivizes participation in markets, which leads to higher efficiency. Harcourt (2011) faults Becker for taking the criminal code as given.

8"Big Corporations Bankroll Seminars For U.S. Judges," Washington Post, 20 Jan 1980, available at washingtonpost.com/archive/politics/1980/01/20/big-corporations-bankroll-seminars-for-usjudges /8385bf9f-1eb7-451a-8f3d-bdabb4648452/. See Appendix B for more background and documents related to the Manne Program. 
year, until 1999. By 1990, forty percent of federal judges had attended this program. ${ }^{9}$

In the Appendix, we provide extensive qualitative evidence on how the program was perceived by the public and the judicial participants, along with extensive quotations from judges who enthused about the program. The quotes testify to how much the judges appreciated the program, how demanding were the lessons, and how the judges learned to think about their rulings through cost-benefit analysis rather than more traditional legal reasoning.

Lectures were by eminent economists including Milton Friedman, Paul Samuelson, Armen Alchian, Harold Demsetz, Martin Feldstein, and Orley Ashenfelter. Topics covered Coase Theorem, demand/supply theory, consumer/producer/price theory, bargaining, externalities, expected value/utility, property rights, torts, contracts, monopoly theory, regulation, and statistics, and basic regression. The main reading material were economics articles and textbooks, such as Law and Economics by Robert Cooter and Thomas Ulen, and Exchange and Production by Armen Alchian and William Allen. The material on criminal law was based on the Becker model and deterrence theory. There was no material on behavioral economics nor more sophisticated law and economic theories, such as over-deterrence, according to the syllabi listed in Butler (1999).

The annual reports also include the instructors' views. In terms of the main lessons, the program strove for ideological balance. Both conservative and liberal economic thinkers were invited. Empirical panels could include both Orley Ashenfelter and John Lott, for example. The former director Henry Butler (personal communication) writes: "Samuelson [lectured] on whatever the heck he wanted to, usually personal investment strategies; Friedman always started on legalization of recreational drugs; Ashenfelter used climate to predict quality and prices of wine, followed by wine tasting." It is clear there was an effort to teach standard econometrics in a relatively enjoyable environment.

Despite this balanced list of instructors, the instruction itself was more emphatically delivered by the conservative instructors. As George Priest, a regular participant, observed "[Manne] did not provide for too much balance...[the liberal economists] were cabined by topics far from familiar to them....A liberal economist teaching supply and demand is hardly dangerous." (Priest 1999, pp. 330). Manne himself (who taught part of the course) articulated the view that insider trading was economically efficient. He writes: "It is ironic that the word 'profit' has become a swear word, since profit is

\footnotetext{
${ }^{9}$ Hundreds of judges attended, despite "being swamped with criminal cases ... and not seeing the relevance of economics" (Butler, 1999). Ironically, we will see below that economics did impact sentencing.
} 
the only decent measure of the real public benefit provided by business." Another instructor, Professor Goetz, defended "'Unequal' Punishment for 'Equal' Crime," arguing that discrimination in punishment can be economically efficient. In more recent years, the annual reports include instructors with known conservative stances on immigration (George Borjas), crime (James Q. Wilson), and family law (Jennifer Roback Morse, founder of the ant-LGBT Ruth Institute). In a Fortune magazine article (May 21, 1979), instructors quotes indicate how normative the economics instructors intended to be. Alchian said, "I'm trying to change your view of the world, to show you that what you thought was bad really may not be." Klein and Demsetz gave the receieved views on antitrust: "price discrimination, which encourages production is good", and the view of judge being social planner: "the consumer who is supposed to benefit .. isn't represented; he isn't there in front of you with his lawyer". On damages and deterrence, Demsetz said motivated increase in sanctions as, "[an agent is] not likely to be caught, [so] the threat of simple damages may not be a tough enough deterrent" and the moral hazard associated with damages: "The plaintiffs may wait a long time before they complain, because they want damages to pile up." On environmental law, Alchian stated, "Give me a capsule that will magically clean all the air in Los Angeles ... Beg me to crush it. ... I won't crush the capsule. Because, if I do, poor blacks will have to pay \$20 a month more for land rental. ... the black in Watts, already used to living with bad air, loses his discount for doing that." On equal opportunity and discrimination, Feldstein said, "you should be asking questions like, 'Is it more likely to be this than that?'", but no empirical skepticism towards antitrust theory was articulated. As a testimony to the program impact, Judge Williams, then fresh out of the center's program, included a diagram of marginal- and average-cost curves "the first significant opinion in history to do that".

In summary, we have a two-week, eight-hours-a-day intensive economics course attended by almost half of federal judges over the span of twenty years. ${ }^{10}$ The program has a recognized conservative bias, yet the attending judges are effusive in their praise regardless of ideological standpoint. What is the impact on observed judge decisions?

\section{Data}

This section describes our data sources.

\footnotetext{
${ }^{10}$ Thus, this program induces much more intensive exposure to information than many other informational interventions that have long run effects,e.g. Jensen (2010) on returns to schooling.
} 
Figure 1: Share of Cases with Manne Judge on Panel, 1900-2010

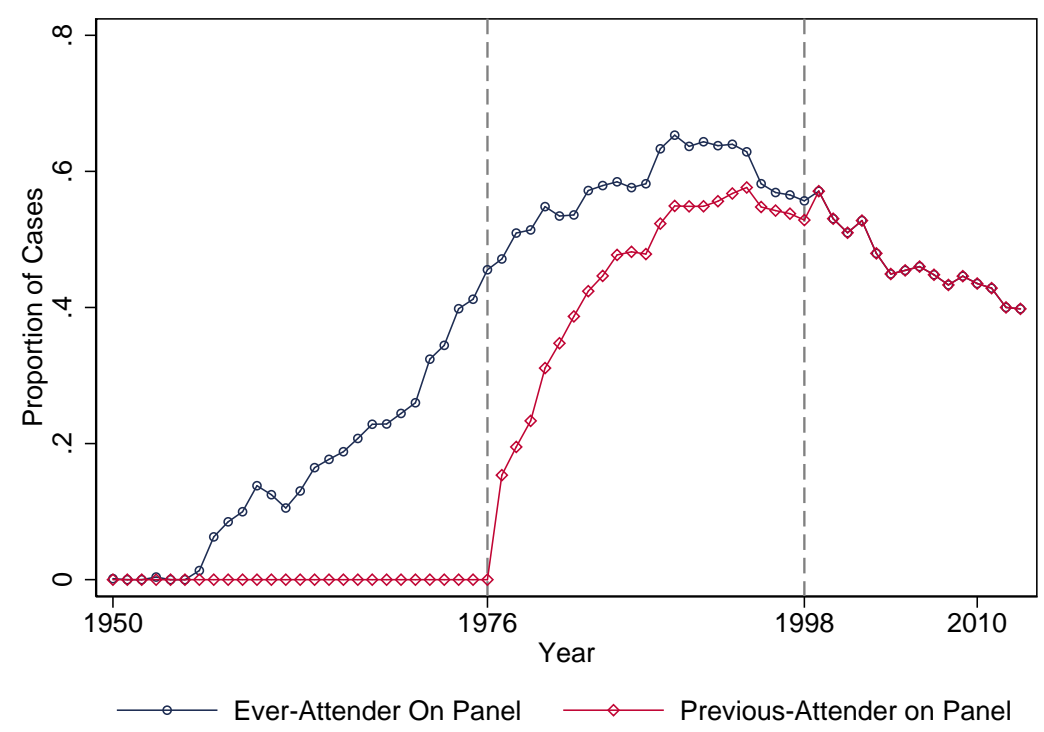

Notes. Share of cases with a Manne judge on the panel, plotted by year. Blue line gives judges who ever attended; red line gives judges who have already attended.

\subsection{Federal Judges Data and Randomization}

We begin with the data on federal circuit and district judges from the Federal Judicial Center.

To the FJC data we have added the record of attendance by all federal judges to the Manne program, 1976-1999. Butler (1999) contained a list of all the judges that had attended through 1999, when the program as such ended (other economics trainings continued but were on more specific topics, e.g. antitrust). We supplemented this list with exact years of attendance from Annual Reports obtained by filing FOIA requests and correspondence from the Law and Economics Center at George Mason University. Figure 1 plots the share of Circuit Court cases with a Manne Judge on the panel over time. As can be seen, by the late nineties, about half of cases were directly impacted by a Manne panelist.

A major concern in an empirical analysis of the Manne program is endogenous selection into the program, both in terms of the type of judge and, within-judge, the timing of attendance. Even in a dynamic panel framework, it could be that judges who at some point decide they like economics or conservatism then decide due to this 
ideological shift to attend the Manne Program. In Appendix Tables 15 and 16, we assess differences across judges on observables, using all control variables as well as control variables chosen using elastic net (regularization parameter chosen with crossvalidation). Unsurprisingly, there are significant differences between Manne and nonManne judges. Republicans are a little more likely to go, but as seen from the quotes, many Democrats went as well. Judges born in the 1910s are less likely to attend, as they are old, as are the ones born in the 1950s, who may have already received law and economics training in law school. In addition, there are differences in the Manne judges that attended earlier rather than later. But for the timing regression, many of the selected variables are indicators for the birth cohort of the judge. This is just an accident of judge generational timing, rather than evidence of consistent ideological differences. We will control for the selected characteristics, fully interacted with year fixed effects. For example, we allow Republicans and Democrats to have different intercepts for each year.

Besides endogenous selection into the program, we are also worried about endogenous selection of judges to cases. In Circuit Courts, each case is randomly assigned to a panel of three judges. The judges are drawn from a pool of 8-40 judges. We have assessed judge randomization through interviews of courts and orthogonality checks on observables. ${ }^{11}$ The process in recent years is as follows. Two to three weeks before oral argument, a computer randomly assigned available judges to a case, including visiting judges. It ensures that judges are not sitting together repeatedly, and ensures that senior judges have fewer cases. Judges can occasionally recuse themselves. On appeal after remand, the same panel reviews a case. There are exceptions to randomization for rare specialized cases such as those involving the death penalty.

We assume these deviations from randomness are independent of our main effects, though we also report omnibus checks of whether Manne judges are systematically more or less likely to author or sit on economics cases. ${ }^{12}$ Appendix Table 17 shows that randomness does not appear to be violated in the context of Manne judges and the proportion of cases published on economics topics. In addition, they do not selectively

\footnotetext{
${ }^{11}$ For example, Chen and Sethi (2011) use data from Boyd et al. (2010) and Sunstein et al. (2006), who code 19 case characteristics as determined by the lower court for 415 gender-discrimination Circuit Court cases, and find that case characteristics are uncorrelated with judicial panel composition. Other papers examine whether the sequence of judges assigned to cases in each Circuit Court mimics a random process. They find, for example, that the string of judges assigned to cases is statistically indistinguishable from a random string.

${ }^{12}$ Economics cases are defined as the "regulation" and "labor" categories. See Table 14 in the Appendix for information on the distribution of cases.
} 
Figure 2: Ellickson Phrases

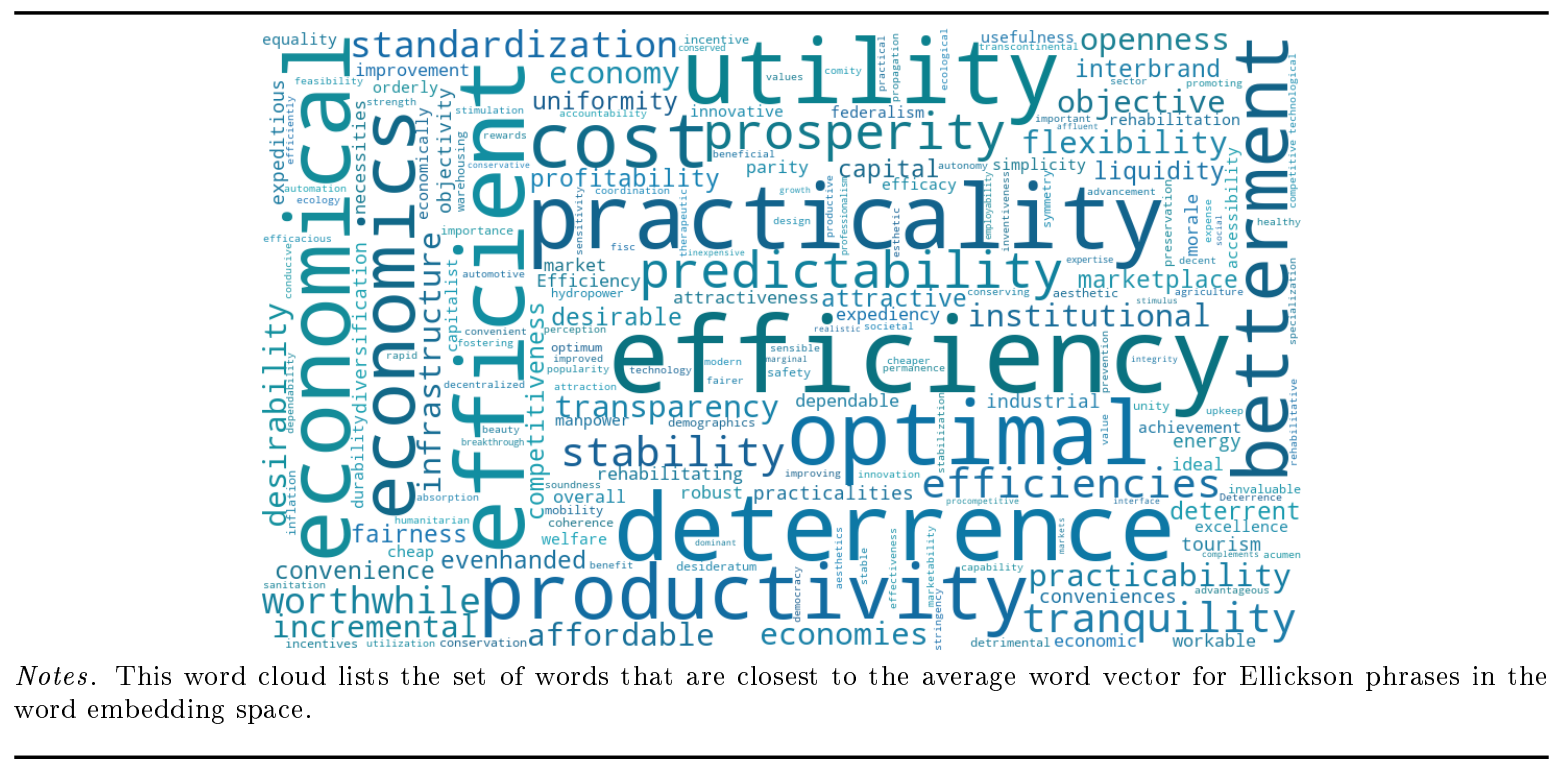

author more economics cases.

\subsection{Measuring Economics Style In Judicial Language}

This section describes how we measure the influence of law and economics in the judiciary using the wording of written decisions. We have access to a transparent measure of economics language similarity based on an index of phrases. Specifically, we use an index of law-and-economics phrases used by Ellickson (2000) for the purposes of identifying law-and-economics articles in a corpus of law journal articles. ${ }^{13}$ This index includes nine phrases that are characteristic of the use of economic analysis in legal contexts, and we take the words from these phrases.

We construct two measures of economics style from this set of phrases. First, we take the average frequency of these phrases per opinion. Second, we construct document embeddings for each case following the method of Arora et al. (2017). This method starts by training Word2Vec embeddings on our corpus, where words that are related to each other are located near to each other in the vector space. We then take a case as the average of the vectors for each word in the case, weighted by inverse frequency (so rare, more informative, words are upweighted in constructing the vectors. We take the

\footnotetext{
${ }^{13}$ Ellickson used the following Lexis wildcards: externalit*, transaction_costs, efficien*, deterr*, cost_benefit, capital, game_theo, chicago_school, marketplace, law1economic, law2economic.
} 
Figure 3: Trends in Law-and-Economics Rhetoric
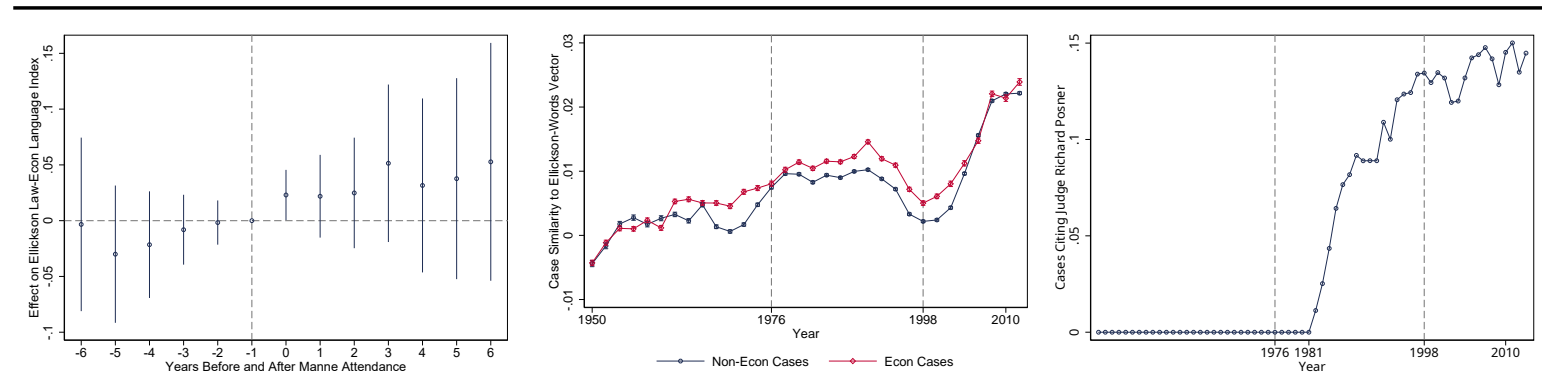

Notes. Average Ellickson phrase frequency (left panel), similarity to Ellickson words vector (middle panel), and cases citing Judge Richard Posner, plotted by biennium and separately by economics cases (regulation and labor) and other cases. Error spikes give standard error of the mean.

average word vector for the words in the Ellickson Index, and then compute the cosine similarity of each case vector to that averaged vector. The set of words that are closest to the Ellickson Vector are shown in Figure 2, where the size of the word corresponds to the closeness to the vector.

Figure 3 shows the trend in these measures (the average frequency of Ellickson Index phrases, and the avereage case similarity to the Ellickson Index vector) since 1950. We see that in general, economics cases score more highly on the measures, as expected. In addition, the measures have in general been increasing over time.

In the right panel, we also show that citations to the decisions of law-econ luminary Richard Posner have also been increasing over time as a share of circuit cases. About one in seven decisions cites Judge Posner in recent years, speaking to the influence of law-and-economics ideas.

\subsection{Judicial Decision Outcomes}

This subsection outlines the judicial decision outcomes used in the analysis.

\subsubsection{Conservative Judicial Decisions}

Our primary outcomes will be proxies for conservative judicial opinion. Our first measure of conservative judicial opinion relies on the Songer database of $5 \%$ of Circuit cases. The $5 \%$ sample was also hand-labeled for vote valence: liberal, conservative or neutral/hard-to-code. The Songer Database defines conservative vote to include rejecting the defendant in a criminal procedure case, rejecting a plaintiff asserting violation 
Figure 4: Increasing Conservative Vote Rate

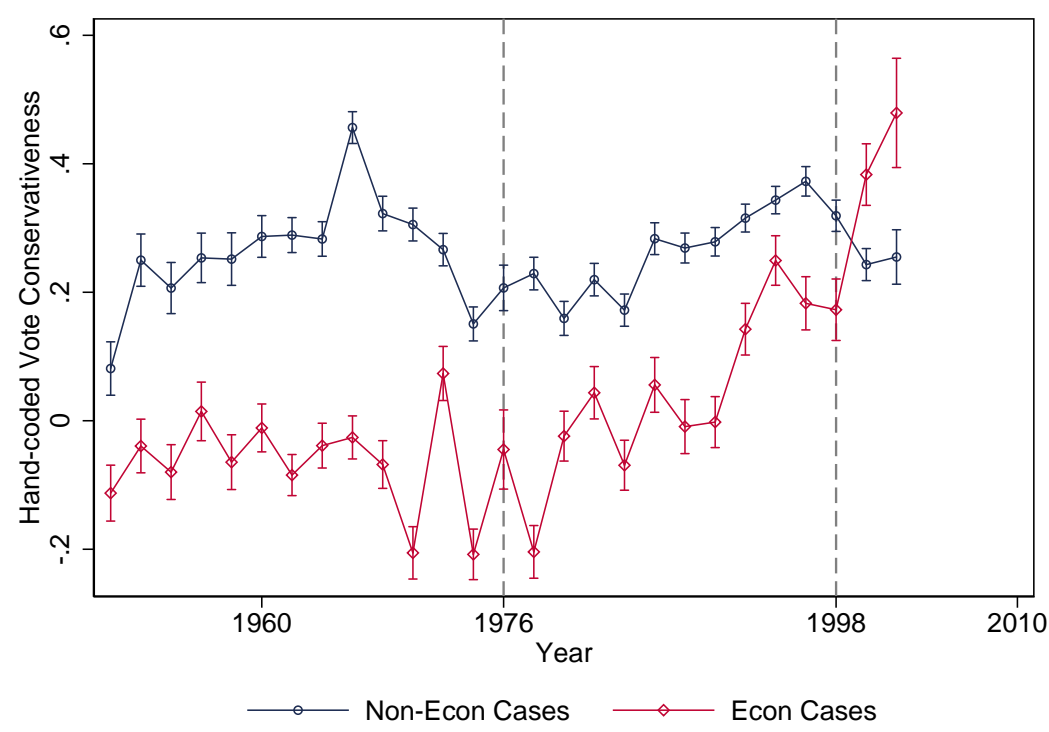

Notes. Average conservative vote rate circuit courts using $5 \%$ hand-coded Songer Auburn data, plotted by year. Error spikes give standard error of the mean. Data weighted to treat judge-years equally.

of First Amendment rights, and rejecting the Secretary of Labor who sues a corporation for violation of child labor regulations. Figure 4 shows the trend in conservatism over time. It has increased since the late 1970s.

We might expect stronger effects for economics rather than non-economics cases as the latter can include social issues like abortion or drug policy, where the effect of economic thinking could be libertarian, and therefore coded as "liberal" by the Songer database. We define as "Economics Case" the categories labor and regulation. ${ }^{14}$

\subsubsection{Regulation}

The Songer-Auburn measure provides an intuitive measure of conservatism. But it is hand-coded, which could lead to coding errors and subjective decisions. In addition, one might worry that the use of economic reasoning itself might be coded as conservative. Therefore we complement this measure with a machine-coded measure from the available metadata in the case.

In particular, we look at regulatory cases. We know from the party of the case

\footnotetext{
${ }^{14}$ See Table 14 in the Appendix for information on the distribution of cases.
} 
whether a labor agency or an environmental agency is party to a case. The labor agencies include the National Labor Relations Board, Office of Worker's Compensation Programs, U.S. Department of Labor, Federal Labor Relations Authority, and Occupational Safety and Health Administration. The included environmental agency is the Environmental Protection Agency. We construct measures based on the voting of judges over the outcomes. We use voting against government in regulatory cases as another measure of conservative decision-making.

\subsubsection{Taxation}

Besides regulations for workers and the environment, federal judges play an important role in navigating disputes between taxpayers and the Internal Revenue Service (IRS). There are many cases per year where the IRS and taxpayers end up in court about taxes owed. Meanwhile, the standard economics models are generally in support of the fiscally conservative position that taxes are distortionary and therefore should be kept as low as possible. Therefore, judges that learn the basic economics of taxation might be more skeptical of supporting the IRS in these disputes. Our measure of conservatism in this context is voting against the IRS in tax disputes.

\subsubsection{Effect on Criminal Decisions}

We obtain data on criminal sentencing by federal district judges from Transactional Records Access Clearinghouse (TRAC). Extensive description of these data is available elsewhere (Yang 2014). The FOIA data comes merged with judge identity for the years 1992 through 2011 in two overlapping samples. ${ }^{15}$ For the years 1992 through 2003 (used for the within-judge event study), there are approximately 1.03 million cases. For the years 1999 through 2011 (used for analyzing the effect of discretion provided in Booker), there are approximately 856,000 cases.

We drop life sentences and fines (which are less than $1 \%$ of the sample). Besides the judge and sentencing date, we have detailed information on the type of crime and the sentence imposed. ${ }^{16}$ We focus on prison sentence outcomes. We look at whether

\footnotetext{
${ }^{15}$ There are duplicates, so we present the analyses separately.

${ }^{16}$ The data contain information on prison sentences, probation sentences, fines, and the death penalty. We do not consider the death penalty, as it is exceedingly rare in federal cases (71 cases). Probation sentences and monetary fines are much more frequent but still apply in only about $10 \%$ of the cases each. Monetary fines are mostly very small relative to prison sentences. The median non-zero monetary fine is $\$ 2,000$, and the 90 th percentile is $\$ 15,000$. We thus ignore them as well, and focus exclusively on prison sentences.
} 
any prison was imposed, and the log length of the imposed sentence in days (plus one).

\section{Direct Effect of Manne Attendance}

This section provides the specification and results of attending the manne program on judge behavior.

\subsection{Specification}

The causal effect $\gamma$ of assignment of judge $j$ on case $i$ in court $c$ and year $t$ on outcome $Y:$

$$
Y_{i j c t}=\alpha_{i j c t}+\gamma Z_{j c t}+X_{j c t}^{\prime} \beta+\epsilon_{i j c t}
$$

The outcome $Y_{i j c t}$ is measured in the four ways described above: 1) use of economics style language, 2) conservative vs. liberal vote in the $5 \%$ hand-coded sample, 3) voting against government in regulatory cases (machine-coded for the $100 \%$ sample), and 4) length of criminal sentence in the district court (a 100\% sample, which we FOIA-requested to include the judge identity). The treatment variable $Z_{j c t}$ is simply a dummy variable equaling one for years after a judge attends the Manne program, or zero otherwise. The error term is $\epsilon_{i j c t}$.

All specifications also include fixed effects represented in the term $\alpha_{i j c t}$. The preferred specification is a full set of judge fixed effects, and a full set of circuit-year interacted fixed effects, in order to isolate variation in the treatment variable $Z$ due to random assignment of judges across panels in the court docket. We also check for robustness to the inclusion of judge characteristics, interacted with year, given by $X_{j c t}$. As shown earlier in the covariate balance section, we focus on judge $j$ 's political party, birth cohort, and previous government occupations predictive of attendance. These controls are useful for addressing the major threat to identification, endogenous attendance and endogenous timing of attendance.

The treatment is essentially the judge, so we cluster by judge. Clustering standard errors by circuit or circuit-year or judge and case increases the statistical significance of the results. In addition, we re-weight the cases to account for variation in the size of the caseload, such that judge-years are weighted equally.

Alongside the tables, we report our results using an event study approach. We 
Figure 5: Manne Attendance and Appellate Rulings Against Labor/Environmental Agencies
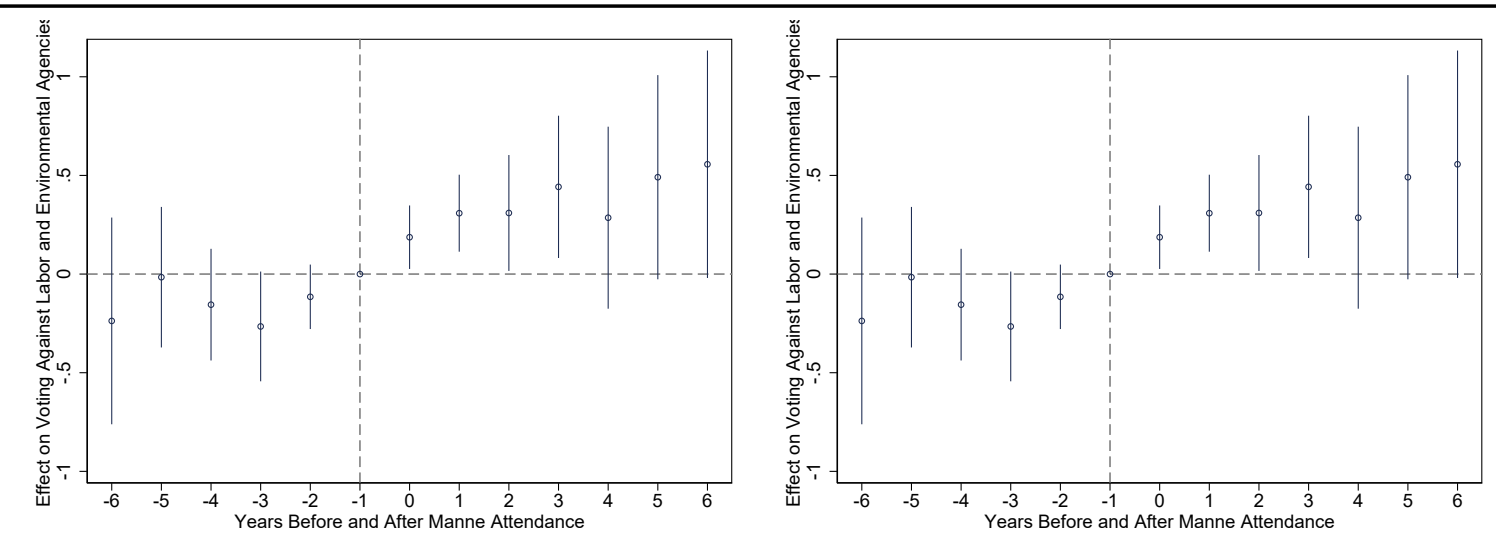

Notes. Event study effects on voting against government agency on labor and environmental issues, relative to year before attendance at Manne economics training. Regressions include judge and circuit-year fixed effects. Right panel also includes elastic-net-selected controls interacted with year dummies. Error spikes give $95 \%$ confidence intervals.

estimate

$$
Y_{i j c t}=\alpha_{i j c t}+\sum_{n \in N} \gamma_{n} Z_{j c t+n}+X_{j c t}^{\prime} \beta+\epsilon_{i j c t}
$$

where we ave the event study time window $N \in\{-6,-5, \ldots,-2,0,1, \ldots, 6\}$. The year before attendance $(n=-1)$ is the excluded year from which coefficients are computed. The indicators $Z$ correspond to the leads and lags of Manne attendance.

\subsection{Manne Effect on Regulatory Decisions}

We begin with judicial decisions, voting against federal regulatory agencies, particularly those entrusted with enforcing labor and environmental regulation.

We focus on two types of agencies the Law and Economics movement specifically criticized: the labor agencies (especially the National Labor Relations Board and Department of Labor) and the Environmental Protection Agency. Figure 5 shows the event study estimates for Manne attendance on these vote rates. Manne judges exhibit a sharp and sudden increase in propensity to vote against federal labor and environmental regulatory agencies. The right panel includes, in addition to the fixed effects, the full range of elastic-net-selected controls for timing of attendance. If anything, it increases the significance of our estimates. The figure indicates no marked pre-trend, and if anything, a tendency to vote in the opposite direction before attendance. This 
Table 1: Manne Training and Labor/Environmental Cases

\begin{tabular}{|c|c|c|c|c|}
\hline \multirow{3}{*}{ Econ Training X Post Manne } & \multicolumn{4}{|c|}{ Voting Against Environmental or Labor Agency } \\
\hline & $(1)$ & $(2)$ & $(3)$ & $(4)$ \\
\hline & $\begin{array}{l}0.101 * * \\
(0.0315)\end{array}$ & $\begin{array}{l}0.0939 * * \\
(0.0298)\end{array}$ & $\begin{array}{l}0.165^{* *} \\
(0.0376)\end{array}$ & $\begin{array}{l}0.144^{* *} \\
(0.0305)\end{array}$ \\
\hline $\mathrm{N}$ & 19521 & 19521 & 19521 & 19521 \\
\hline adj. R-sq. & 0.307 & 0.311 & 0.319 & 0.337 \\
\hline Circuit-Year FE & $\mathrm{X}$ & $\mathrm{X}$ & $\mathrm{X}$ & $\mathrm{X}$ \\
\hline Judge FE & $\mathrm{X}$ & $\mathrm{X}$ & $\mathrm{X}$ & $\mathrm{X}$ \\
\hline Party $\times$ Year FE & & $\mathrm{X}$ & $\mathrm{X}$ & $\mathrm{X}$ \\
\hline Ever-Attend $\times$ Year FE & & & $\mathrm{X}$ & $\mathrm{X}$ \\
\hline E-net-Vars $\times$ Year FE & & & & $\mathrm{X}$ \\
\hline $\begin{array}{l}\text { Effect of Manne economics training on } \\
\text { ge. Observations are weighted to treat } \\
\text { h } 2005 \text {. }\end{array}$ & ing again & $\begin{array}{l}\text { bor and envi } \\
\text { lly. }+p<.1\end{array}$ & $\begin{array}{l}\text { Imental ge } \\
p<0.05,\end{array}$ & $\begin{array}{l}\text { ndard errors clus } \\
\text { 1. Includes years }\end{array}$ \\
\hline
\end{tabular}

suggests that the program changed the direction of their votes, not simply giving them tools to actualize their votes.

The regression results are reported in Table 1. We see an increase in voting against labor/environment agencies due to Manne attendance. This result is robust to the inclusion of party-year fixed effects (2), ever-attend-year fixed effects (3), and the set of variables associated with attendance timing selected by elastic net (4). Judges are roughly 10 percentage points more likely to rule against environmental and labor regulations after Manne attendance.

\subsection{Manne Effect onTaxation Decisions}

The next outcome we look at is voting against the federal tax authority. Figure 6 shows the event study estimates for Manne attendance on vote rates against the IRS. We see that, as in the case of the regulatory agencies, Manne judges have a sharp increase in voting against the IRS. Again, we do not see much of a pre-trend, and if anything, a tendency to vote in the opposite direction before attendance. This suggests that the program changed the direction of their votes, not simply giving them tools to actualize their votes. 
Figure 6: Manne Attendance and Appellate Rulings Against Internal Revenue Service

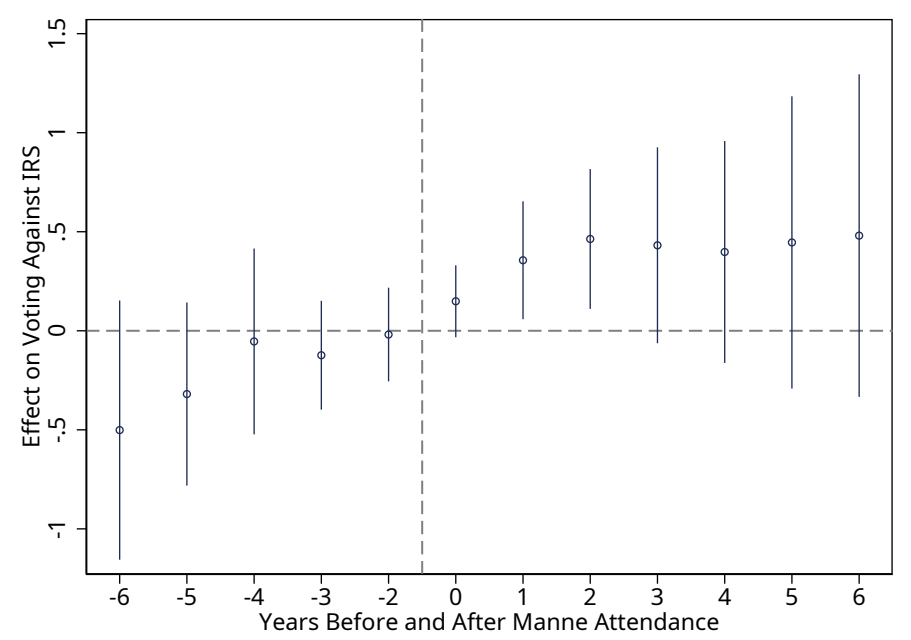

Notes. Event study effects on voting against the IRS, relative to the year before attendance at Manne economics training. Regressions include judge fixed effects, circuit-year fixed effects, and elastic-net-selected controls interacted with year dummies. Error spikes give $95 \%$ confidence intervals.

Table 2: Manne Training and Taxation Cases

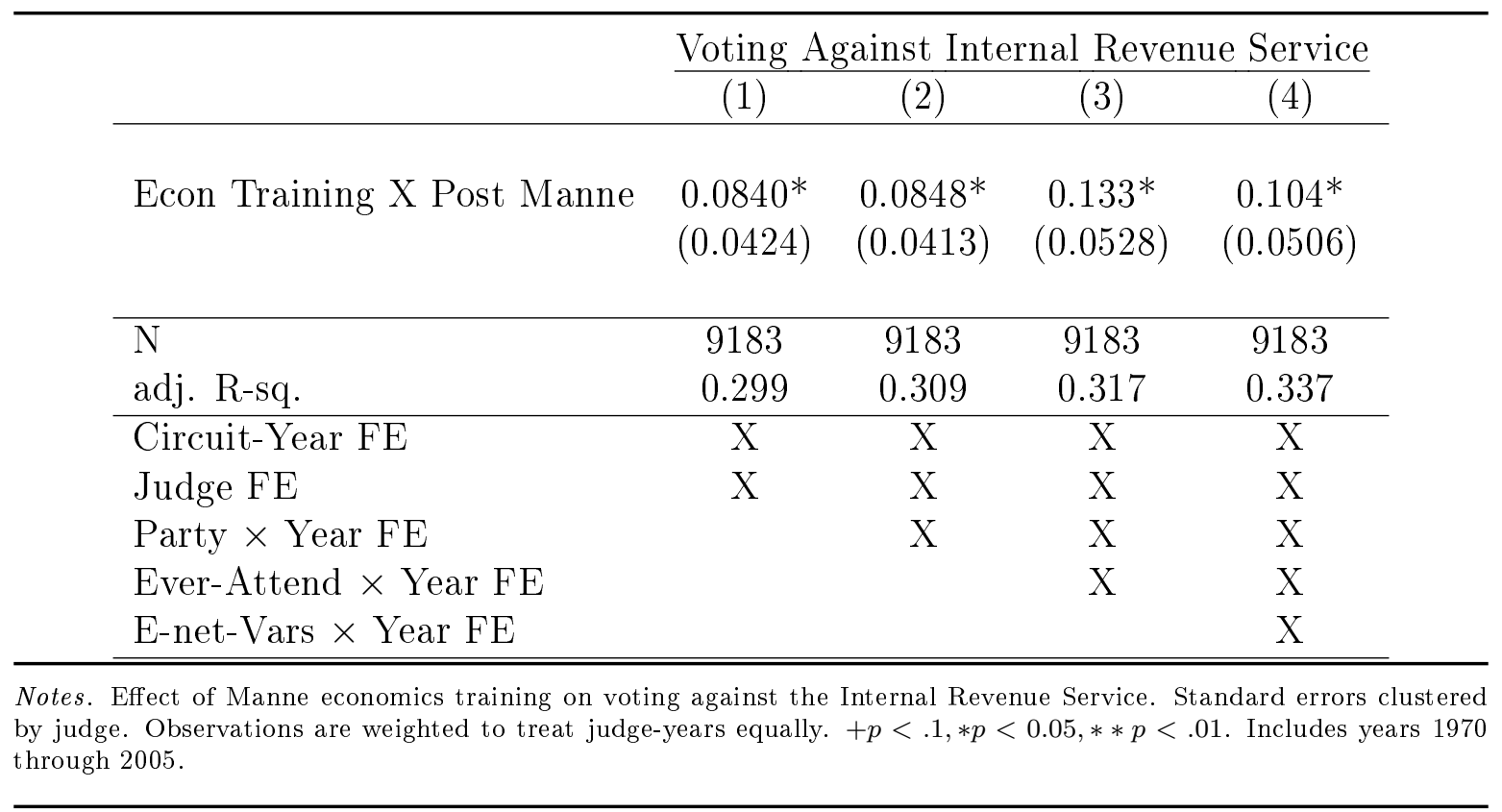


Figure 7: Manne Law-and-Econ Attendance and Songer-Auburn Conservative Vote

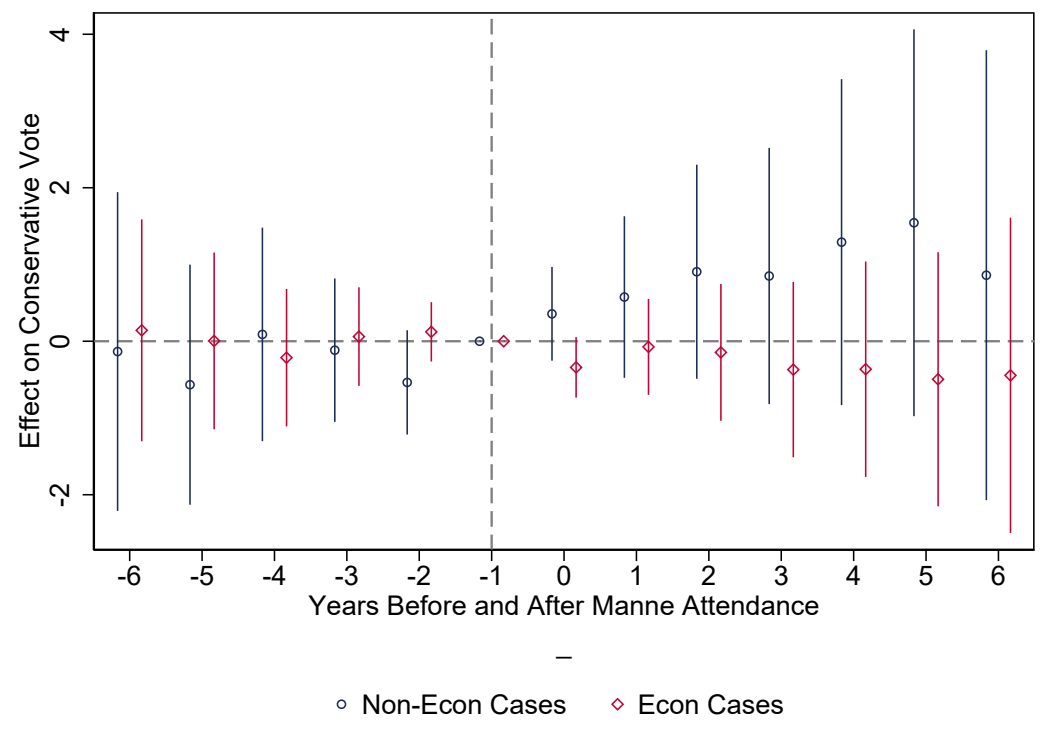

Notes. Event study effect on conservative vote in economics cases (regulation and labor; in red) and non-economics cases (in blue). Regressions include judge and circuit-year fixed effects. Observations are weighted to treat judge-years equally. Error spikes give $95 \%$ confidence intervals.

The regression results are reported in Table 2 . We see an increase in voting against tax agencies due to Manne attendance. As before, this result is robust to the inclusion of party-year fixed effects (2), ever-attend-year fixed effects (3), and the set of variables associated with attendance timing selected by elastic net, interacted with year (4). Judges are roughly 10 percentage points more likely to rule against the tax authority after Manne attendance.

\subsection{Manne Judges and Conservativeness of Decisions}

Next we analyze the relationship between economics in the circuit courts and conservative voting, as hand-coded in the 5\% sample Songer Database. We look at whether and how conservativeness is related to attendance at the Manne program.

Figure 7 shows the event study estimated for effect of Manne attendance on conservative vote. In red, we subset on economics cases (labor and regulation), which is roughly $30 \%$ of the sample. In blue, we subset on non-economics cases (everything else). We can see a clear positive trend break in the conservativeness of votes in economics cases, which seems to persists over multiple years. There is not much effect in 
Table 3: Diff-in-Diff Impact of Economics Training on Conservative Votes

\begin{tabular}{|c|c|c|c|c|}
\hline & Con & servative I & ote $(+1 / 0$ & $(-1)$ \\
\hline & (1) & $(2)$ & $(3)$ & $(4)$ \\
\hline Econ Case & $\begin{array}{c}-0.202^{* *} \\
(0.0274)\end{array}$ & $\begin{array}{c}-0.201^{* *} \\
(0.0271)\end{array}$ & $\begin{array}{c}-0.204^{* *} \\
(0.0266)\end{array}$ & $\begin{array}{c}-0.210^{* *} \\
(0.0250\end{array}$ \\
\hline Post-Manne & $\begin{array}{l}-0.0327 \\
(0.0684)\end{array}$ & $\begin{array}{l}-0.0235 \\
(0.0663)\end{array}$ & $\begin{array}{c}0.0267 \\
(0.0841)\end{array}$ & $\begin{array}{c}0.0292 \\
(0.0819)\end{array}$ \\
\hline $\begin{array}{l}\text { Econ Case } \\
\text { Post-Manne }\end{array}$ & $\begin{array}{c}0.125+ \\
(0.0692)\end{array}$ & $\begin{array}{c}0.126+ \\
(0.0681)\end{array}$ & $\begin{array}{c}0.113+ \\
(0.0655)\end{array}$ & $\begin{array}{c}0.121+ \\
(0.0618)\end{array}$ \\
\hline $\mathrm{N}$ & 27799 & 27799 & 27799 & 27799 \\
\hline adj. R-sq & 0.221 & 0.224 & 0.227 & 0.242 \\
\hline Circuit-Year FE & $\mathrm{X}$ & $\mathrm{X}$ & $\mathrm{X}$ & $\mathrm{X}$ \\
\hline Judge FE & $\mathrm{X}$ & $\mathrm{X}$ & $\mathrm{X}$ & $\mathrm{X}$ \\
\hline Party $\times$ Year FE & & $\mathrm{X}$ & $\mathrm{X}$ & $\mathrm{X}$ \\
\hline Ever-Attend $\times$ Year FE & & & $\mathrm{X}$ & $\mathrm{X}$ \\
\hline E-net-Vars $\times$ Year FE & & & & $\mathrm{X}$ \\
\hline
\end{tabular}

non-economics cases; it looks like a small negative effect, which might be expected if economic thinking imparts a libertarian view on social policy, which would have been coded as liberal by Songer, so in our regression analysis we will interact the treatment with economics case. In neither group of cases do we see significant pre-trends.

Table 3 presents the regressions for economics training and conservative votes. We analyze the diff-in-diff effect using the year-by-year attendance data for the program's heyday. The differences-in-differences analysis includes circuit-year fixed effects and judge fixed effects, and renders a consistent picture that Manne judges become more conservative after the training relative to their colleagues. In particular, in Column 4 we add the elastic-net-selected control variables associated with Manne attendance, fully interacted with year fixed effects. This tends to strengthen the results $(p=.051)$. Judges shift by 10 percentage points the direction of their votes after Manne attendance. 
Figure 8: Manne Law-and-Economics Attendance and Economics Style
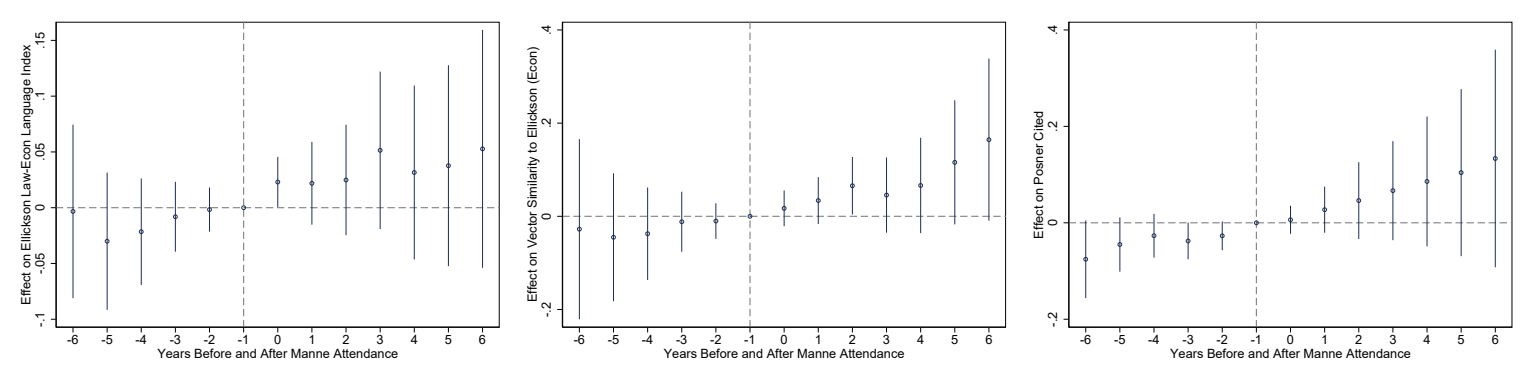

Notes. Left panel: event study effect on Ellickson Law-and-Economics Index, with elastic net controls interacted with year; middle panel: event study effect on Ellickson Embedding Similarity in economics cases, with judge trends; right panel: Effect on citations to Judge Posner, with judge trends. Regressions include judge and circuit-year fixed effects. Observations are weighted to treat judge-years equally. Error spikes give $95 \%$ confidence intervals.

To interpret the magnitudes, from 1976 to 2002, Songer database documents an increase of 0.3 in the likelihood to vote conservative rather than liberal. Taking the Manne coefficient of 0.2 and multiplying by 0.4 (the percentage of federal judges who attended) renders a substantial fraction of the overall 0.3 shift. If the historical time period to explain begins a bit earlier, then the historical change has been 0.2 since the mid-1970s. Taken together, these numbers imply the Manne program accounts for $28-42 \%$ of the rise in judicial conservatism. Note that the regression estimates only account for own-attendance. If peers and precedent also impact the non-Manne judges, then the true Manne impact may be larger than 0.2, and thus explain an even larger portion of the historical shift.

\subsection{Manne Effect on Judicial Language}

We ask the basic question of whether judges who attend law and economics training actually use the language of law and economics in their opinions. Figure 8 provides the event study estimates. The outcome variables are our measures of economics style, defined as Ellickson Index Frequency (left panel) and Ellickson Embedding Similarity (middle panel). We see that on both measures, judges who attend the Manne program increase their use of economics style in written judicial opinions. There may be a small pre-trend, but there is a discrete jump in the year after attendance. ${ }^{17}$ In addition, in the right panel we see that there are increases in citing Posner after Manne attendance,

\footnotetext{
${ }^{17}$ We include judge trends for the Ellickson embedding and Psoner cites because it reduced the pre-trend.
} 
Table 4: Effect of Manne Attendance on Judicial Language

\begin{tabular}{|c|c|c|c|c|}
\hline & Ellickson & quency Index & Embedding & Posner Cited \\
\hline & $(1)$ & $(2)$ & $(3)$ & $(4)$ \\
\hline Manne Post & $0.0105^{*}$ & $0.00992+$ & 0.00525 & $0.00861^{*}$ \\
\hline & $(0.00523)$ & $(0.00512)$ & $(0.00342)$ & $(0.00400)$ \\
\hline $\mathrm{N}$ & 632799 & 632799 & 623874 & 886988 \\
\hline adj. R-sq & 0.060 & 0.060 & 0.075 & 0.194 \\
\hline Circuit-Year FE & $\mathrm{X}$ & $\mathrm{X}$ & $\mathrm{X}$ & $\mathrm{X}$ \\
\hline Judge FE & $\mathrm{X}$ & $\mathrm{X}$ & $\mathrm{X}$ & $\mathrm{X}$ \\
\hline Party $\times$ Year FE & & $\mathrm{X}$ & $\mathrm{X}$ & $\mathrm{X}$ \\
\hline $\begin{array}{l}\text { Notes. Panel estimated of effect } \\
\text { 3), Ellickson Econ Embedding } \\
\text { clustered at the judge level in pa } \\
\text { years equally. }\end{array}$ & $\begin{array}{l}\text { manne tra } \\
\text { milarity }(\mathrm{C} \\
\text { entheses. }\end{array}$ & $\begin{array}{l}\text { on Ellickson Inc } \\
1,4) \text { and Citati } \\
1, * p<0.05, *\end{array}$ & .01 . Observat & $\begin{array}{l}\text { ics language }(\mathrm{Col} \\
\text { Column 5). Stan } \\
\text { are weighted to }\end{array}$ \\
\hline
\end{tabular}

although it appears to be pre-trending.

One might worry that we are not picking up economics language. Instead, we might be picking up the effect on conservative-movement language, or the effect on academic language. We address these issues with two placebo checks. We produce a measure of conservative-movement judges by looking at citatiosn to opinions written by Federal Court nominees put forward by Reagan or George Bush. Second, we produce a measure of non-economic academic language - similarity to law journals for the same time period. We found no effects on our (admittedly rough) proxy for originalism, and if anything, a negative effect on law journal similarity, due to Manne attendance (see Appendix Figure 12).

In Table 4 we report the effects of Manne attendance in a regression framework. There is a positive effect of Manne attendance on the use of law-and-economics language identified by Ellickson (Columns 1 and 2). The Embedding Vector similarity (Column 3) is barely significant $(p=.13)$. Finally, citations to Judge Richard Posner are positively effected and the estimate is statistically significant (Column 4). We got a similar estimate for looking at citations to Posner, Calabresi, and Easterbrook (the three leading law-and-econ judges). In the appendix, we report as placebos the zero effects on Reagan and Bush appointees, meaning that Manne is driven by economics, rather than by general conservatism. 
Figure 9: Event Study: Manne Training and Sentencing Decisions
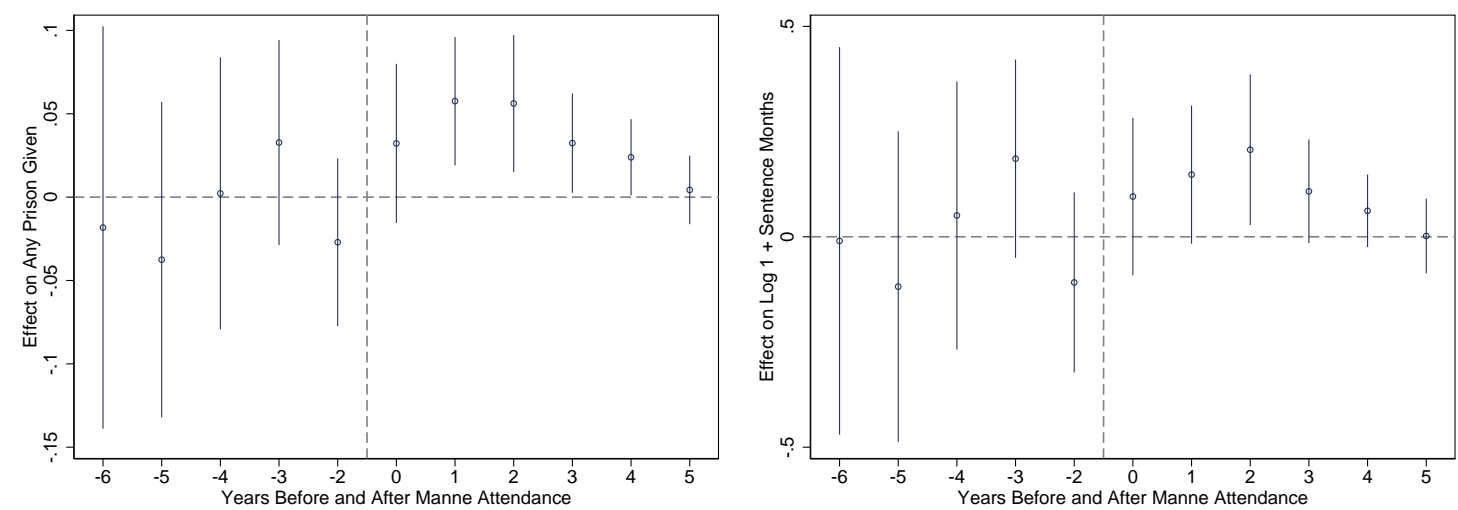

Notes. Event study for effect of Manne economics training on whether any jail sentence is given (left panel) and log of $1+$ sentence length in months (right panel). Regressions include court-year and judge fixed effects. Error spikes give 95\% confidence intervals. Includes data from 1992 to 2003.

\subsection{Changes in Criminal Rulings}

Our next set of results move from the federal appellate courts to the 94 district courts. We look at differences in sentencing between judges trained at Manne and judges not trained in Manne. We also look at the same judge over time.

Figure 9 uses data from 1992 to 2003, where our data has overlap in the sentencing outcomes (beginning in 1992) and in Manne attendance (ending in 1999). This allows a within-judge event study analysis. It shows a lack of pre-trends and that district judges tend to give prison, and tend to render more severe sentences, after attendance at the Manne program. Since this is a fairly short time period, the estimates are somewhat noisy. ${ }^{18}$

In Table 5 and Table 6 we look at the differences-in-differences estimates for how Manne attendance affected district judge sentencing. We find again evidence of harsher penalties. The chance of getting prison time increases by 4 percent, while the length of prison time increases by 13 percentage points. These estimates are robust to weighting judge-years equally or not, to the inclusion of year fixed effects interacted with judge party (Column 3) and ever-attend (Column 4). We also recovered elastic-net-selected covariates predicting attendance timing among district judges; interacting those with year does not change the results (Column 5).

\footnotetext{
${ }^{18}$ We looked at individual crime categories and saw largest effects for drug crimes.
} 
Table 5: Manne Training and Prison Given

\begin{tabular}{lccccc}
\hline & & \multicolumn{3}{c}{ Manne Effect on Any Prison Given } & \\
\cline { 3 - 6 } & $(1)$ & $(2)$ & $(3)$ & $(4)$ & $(5)$ \\
\hline Post Manne & $0.0212^{*}$ & $0.0418^{* *}$ & $0.0355^{*}$ & $0.0399^{*}$ & $0.0421^{*}$ \\
& $(0.00920)$ & $(0.0160)$ & $(0.0161)$ & $(0.0169)$ & $(0.0165)$ \\
& & & & & \\
\hline $\mathrm{N}$ & 1029800 & 1029800 & 980735 & 980735 & 980735 \\
adj. R-sq & 0.073 & 0.100 & 0.092 & 0.092 & 0.093 \\
\hline District-Year FE & $\mathrm{X}$ & $\mathrm{X}$ & $\mathrm{X}$ & $\mathrm{X}$ & $\mathrm{X}$ \\
Judge FE & $\mathrm{X}$ & $\mathrm{X}$ & $\mathrm{X}$ & $\mathrm{X}$ & $\mathrm{X}$ \\
Judge-Year Weights & & $\mathrm{X}$ & $\mathrm{X}$ & $\mathrm{X}$ & $\mathrm{X}$ \\
Party $\times$ Year FE & & & $\mathrm{X}$ & $\mathrm{X}$ & $\mathrm{X}$ \\
Ever-Attend $\times$ year FE & & & & $\mathrm{X}$ & $\mathrm{X}$ \\
E-net-Vars x Year FE & & & & & $\mathrm{X}$ \\
\hline
\end{tabular}

Notes. Diffs-in-diffs estimates for effect of Manne economics training on criminal sentencing outcomes (log of one plus the sentence length, and an indicator for any prison). Standard errors clustered by judge. $+p<.1, * p<0.05, * * p<.01$. Includes years 1992 through 2003.

Table 6: Manne Training and Length of Prison Sentence

\begin{tabular}{|c|c|c|c|c|c|}
\hline & \multicolumn{5}{|c|}{ Manne Effect on Log Sentence Length } \\
\hline & $(1)$ & $(2)$ & $(3)$ & $(4)$ & $(5)$ \\
\hline Post Manne & $\begin{array}{c}0.0833^{*} \\
(0.0366)\end{array}$ & $\begin{array}{c}0.148^{*} \\
(0.0639)\end{array}$ & $\begin{array}{c}0.120+ \\
(0.0650)\end{array}$ & $\begin{array}{c}0.131+ \\
(0.0682)\end{array}$ & $\begin{array}{c}0.133^{*} \\
(0.0666)\end{array}$ \\
\hline $\mathrm{N}$ & 1027409 & 1027409 & 978445 & 978445 & 978445 \\
\hline adj. R-sq & 0.064 & 0.094 & 0.087 & 0.087 & 0.088 \\
\hline District-Year FE & $\mathrm{X}$ & $\mathrm{X}$ & $\mathrm{X}$ & $\mathrm{X}$ & $\mathrm{X}$ \\
\hline Judge FE & $\mathrm{X}$ & $\mathrm{X}$ & $\mathrm{X}$ & $\mathrm{X}$ & $\mathrm{X}$ \\
\hline Judge-Year Weights & & $\mathrm{X}$ & $\mathrm{X}$ & $\mathrm{X}$ & $\mathrm{X}$ \\
\hline Party $\times$ Year FE & & & $\mathrm{X}$ & $\mathrm{X}$ & $\mathrm{X}$ \\
\hline Ever-Attend $\times$ year FE & & & & $\mathrm{X}$ & $\mathrm{X}$ \\
\hline E-net-Vars x Year FE & & & & & $\mathrm{X}$ \\
\hline
\end{tabular}

Notes. Diffs-in-diffs estimates for effect of Manne economics training on criminal sentencing outcomes (log of one plus the sentence length, and an indicator for any prison). Standard errors clustered by judge. $+p<.1, * p<0.05, * * p<.01$. Includes years 1992 through 2003. 
Figure 10: Manne Law and Economics Attendance and Sentencing Decisions
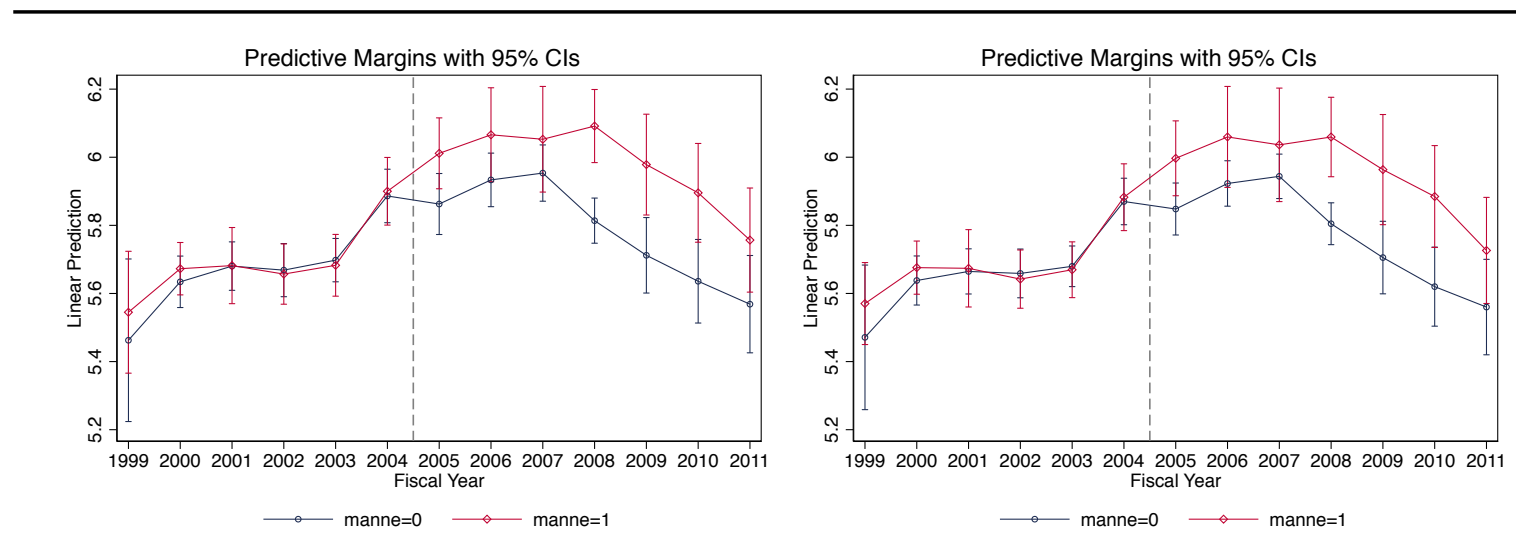

Notes. Log of $1+$ sentence length in days, plotted by year, separately for Manne judges (red) and non-Manne judges (blue). Right panel includes elastic-net-selected biographical controls, interacted with year, and crime type controls. Spikes give $95 \%$ confidence intervals.

Next we look at a 2005 policy change that gives judges more discretion in their sentencing. United States v. Booker loosened the formerly mandatory U.S. Sentencing Guidelines and offers a policy experiment to analyze the effects of judicial discretion. Figure 10 looks at the subsequent data starting in 1999. It shows that economics trained judges render more severe sentences in the fiscal years after Booker. In the cross-section Manne and non-Manne judges made similar decisions prior to Booker, and differences emerge immediately upon Booker.

This result echoes other findings that interjudge sentencing disparities have doubled since the Guidelines became advisory (Yang 2014), and we show that Manne judges contributed to this disparity. Yang (2014) shows that the increase in disparities is associated with judge demographic characteristics, with Democratic and female judges being more likely to exercise their enhanced discretion after Booker. A follow-up study found that Republicans assigned sentence lengths that were $13 \%$ harsher across all District courts, and this lasted for five years.

Accordingly, the right side of Figure 10 controls for available biographical characteristics (and also crime characteristics) as dummy indicators. The results appear hardly affected by these controls. If anything, the pre-Booker sentences are more similar and the post-Booker sentences are more disparate between judges with and without Manne economics training. Moreover, the post-Booker effect of economics is persistent.

The Booker decision was motivated by judges' desire to depart below the guidelines, 
Table 7: Effect of Manne Judges on Criminal Sentencing, Pre- and Post-Booker

\begin{tabular}{|c|c|c|c|c|}
\hline & \multirow{2}{*}{$\frac{\text { Any Sentence }}{(1)}$} & \multicolumn{3}{|c|}{ Log of Total Sentence } \\
\hline & & $(2)$ & $(3)$ & (4) \\
\hline Econ Training & $\begin{array}{l}-0.00433 \\
(0.00692)\end{array}$ & $\begin{array}{l}-0.0336 \\
(0.0594)\end{array}$ & $\begin{array}{l}-0.00527 \\
(0.0462)\end{array}$ & $\begin{array}{c}-0.00795 \\
(0.142)\end{array}$ \\
\hline Booker $(\geq 2005)$ & $\begin{array}{c}0.0400^{* * * *} \\
(0.00600)\end{array}$ & $\begin{array}{c}0.0861 \\
(0.0854)\end{array}$ & $\begin{array}{l}-0.202^{* *} \\
(0.0636)\end{array}$ & . \\
\hline $\begin{array}{l}\text { Econ Training * } \\
\text { Booker }(\geq 2005)\end{array}$ & $\begin{array}{c}0.0117+ \\
(0.00631)\end{array}$ & $\begin{array}{c}0.198^{*} \\
(0.0829)\end{array}$ & $\begin{array}{c}0.131+ \\
(0.0731)\end{array}$ & $\begin{array}{c}0.130+ \\
(0.0774)\end{array}$ \\
\hline $\begin{array}{l}\mathrm{N} \\
\text { adj. R-sq }\end{array}$ & $\begin{array}{c}930448 \\
0.035\end{array}$ & $\begin{array}{c}930448 \\
0.037\end{array}$ & $\begin{array}{c}819881 \\
0.085\end{array}$ & $\begin{array}{c}889951 \\
0.053\end{array}$ \\
\hline $\begin{array}{l}\text { Courthouse and Calendar FE } \\
\text { Judge FE }\end{array}$ & $\mathrm{X}$ & $\mathrm{X}$ & $\mathrm{X}$ & $\begin{array}{l}\mathrm{X} \\
\mathrm{X}\end{array}$ \\
\hline $\begin{array}{l}\text { Sample } \\
\text { Notes. Estimates for impact of Booker, } \\
\text { Standard errors clustered by district in pa } \\
\text { interacted Republican dummies. }\end{array}$ & $\begin{array}{l}\frac{\text { All }}{\text { ne economics tr }} \\
\text { heses. }+p<.1 \text {, }\end{array}$ & $\begin{array}{l}\text { All } \\
\mathrm{gg}, \text { and } \mathrm{t} \\
\mathrm{K} 0.05, *\end{array}$ & $\begin{array}{l}\text { Sentence }>0 \\
\text { interaction on sent } \\
<.01 \text {. Results are }\end{array}$ & 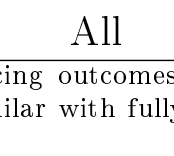 \\
\hline
\end{tabular}

and lower sentence lengths appears to be a long-term trend. We cannot confidently determine whether Manne judges increase their sentences, or non-Manne judges decrease their sentences, since that inference depends on how one fits a trend around Booker.

Formally, we estimate the equation from our baseline specification. We include a full set of courthouse-year interacted fixed effects as well as calendar fixed effects for day-of-week and month-of-sentence. ${ }^{19}$ We condition on courthouse rather than district court because some district courts randomly assign judges within courthouse (Chen and Yeh 2014). ${ }^{20}$ We can include judge fixed effects since Booker varies within judge. We cluster standard errors by district to address unobserved influences affecting the composition of cases within a district.å

Note that the lack of significant difference of Manne judges prior to Booker is not

\footnotetext{
${ }^{19}$ Month-of-sentence always refers to a specific month (e.g., December 1993), not a calendar month (e.g., December).

${ }^{20}$ We employ courthouse fixed effects rather than courthouse by year fixed effects so as to not absorb the post-Booker interaction with Manne judges. We obtain similar results when we only use data from 2004 and 2005.
} 
Table 8: Effect of Manne Judges on Criminal Sentencing, by Crime Type

\begin{tabular}{|c|c|c|c|c|c|}
\hline & \multicolumn{5}{|c|}{ Log of Total Sentence } \\
\hline & $(1)$ & $(2)$ & $(3)$ & $(4)$ & $(5)$ \\
\hline Econ Training & $\begin{array}{l}-0.0695 \\
(0.0839)\end{array}$ & $\begin{array}{l}-0.00621 \\
(0.0347)\end{array}$ & $\begin{array}{l}-0.0369 \\
(0.0559)\end{array}$ & $\begin{array}{l}-0.0213 \\
(0.0619)\end{array}$ & $\begin{array}{l}-0.0226 \\
(0.0599)\end{array}$ \\
\hline $\begin{array}{l}\text { Econ Training * } \\
\text { Booker }(\geq 2005)\end{array}$ & $\begin{array}{l}0.245^{*} \\
(0.100)\end{array}$ & $\begin{array}{c}0.0467 \\
(0.0411)\end{array}$ & $\begin{array}{c}0.200^{*} \\
(0.0856)\end{array}$ & $\begin{array}{c}0.184^{*} \\
(0.0903)\end{array}$ & $\begin{array}{c}0.219^{*} \\
(0.0900)\end{array}$ \\
\hline $\mathrm{N}$ & 600010 & 697844 & 798823 & 838643 & 786472 \\
\hline adj. R-sq & 0.043 & 0.044 & 0.051 & 0.037 & 0.043 \\
\hline Courthouse and Calendar FE & $\mathrm{X}$ & $\mathrm{X}$ & $\mathrm{X}$ & $\mathrm{X}$ & $\mathrm{X}$ \\
\hline Drop Crime & Drug & Immigration & Fraud & Weapon & Other \\
\hline
\end{tabular}

due to sample size: $41 \%$ of the sample is before 2005. The estimated effect of 20 percent longer sentences in Table 7 Column 2 translates to roughly 10 months. Column 1 presents effects on the extensive margin, where Manne judges assign any sentence 1 percentage points more often after Booker, and Column 3 presents the intensive margin, where Manne judges assign 13 percent longer sentence lengths conditional on any sentence. The most restrictive specification is Column 4, which includes judge fixed effects, which also finds 13 percent longer sentence lengths. To benchmark our effect size, blacks receive almost 10 percent longer sentences than comparable white defendants arrested for the same crimes (Rehavi and Starr 2014).

Table 8 shows that the effects are largest when dropping drug crimes. Milton Friedman was known for advocating the legalization of drugs, being against victimless crimes. In addition, harshness is elevated for weapon crimes. The effects are smallest when dropping immigration crimes, suggesting harshness is concentrated for immigration crimes, consistent with results in the Appendix that indicate Manne judges ruled in favor of the ICE after attendance. The vast majority of charges in the immigration category are for (1) reentry of deported alien and (2) entry of alien at improper time or place. Note that, as shown in Appendix Table 18, Manne judges are not differentially appearing on certain types of crimes before or after Booker. 
In the Appendix, we report an additional set of results looking at racial and gender disparities in sentencing. We show that the racial disparity in sentencing between black and white defendants is larger for Manne-trained judges than their colleagues. In addition, the gender disparity in sentencing between make and female defendants is larger for Manne-trained judges than their colleagues. Notably, our results persist controlling for political party of appointment and race (or gender) of the judge. Cohen and Yang (2018) report similar disparities by political party of appointment and use a similar merge as ours.

\section{Spillover Effects and Cultural Transmission}

In this section we ask about the influence of law-and-economics ideas. Did the Manne program affect the judiciary even beyond effects on those that attended? Powerful ideas diffuse readily, and the institutional structure of the Federal courts lets us examine the patterns of intellectual influence exercised by Manne trained judges.

\subsection{Specification}

To measure peer effects, we use the fact that the case law is essentially a book. We can sort by reporter, volume, and page number to examine whether the judge's previous case had a Manne judge and whether any prior case in the Circuit had a Manne judge. Because judges are randomly assigned to panels, they are effectively randomly assigned to sit with Manne or non-Manne colleagues.

The causal effect $\beta_{\mathrm{s}}^{\ell}$ on outcome $F_{i j c t}$ of peer exposure to Manne training for judge $j$ on case $i$ in court $c$ and year $t$ along the exogenous seating network $\mathrm{s}_{i-\ell}^{j}$ for judge $j$ is modeled as:

$$
F_{i j c t}=\sum_{\ell=0}^{L_{\mathrm{s}}} \beta_{\mathrm{s}}^{\ell} \mathrm{s}_{i-\ell}^{j} \mathrm{a}_{i-\ell}^{j}+\sum_{\ell=0}^{L_{\mathrm{d}}} \beta_{\mathrm{t}}^{\ell} \mathrm{t}_{i-\ell}^{j} \mathrm{a}_{i-\ell}^{j}+\mu_{j}+\xi_{c t}+\epsilon_{i j c t}
$$

Outcome $F_{i j c t}$ is a metric for the use of economics language, such as the frequency of "deterrence" or an index previously identified in legal scholarship (Ellickson, 2000). $\mathrm{a}_{i-\ell}^{j}$ is an indicator for the presence of Economics Training on the previous case along the seating network of judge $j$. We run specifications of up to 4 cases back. All specifications include a full set of circuit-year interacted fixed effects, represented in the term $\xi_{c t}$. The error term is $\epsilon_{i j c t}$. 
To control for secular shifts in exposure to Manne judges at the Circuit level, we include as controls (or regress separately for placebo comparison) the presence of Manne trained judges on the previous case along the court network $\mathrm{t}_{i-\ell}^{j}$, which picks up a 'water cooler' effect, if any. Note that the treatment for peer exposure is still the judge, so we cluster by judge, but the placebo treatment varies at the case level, so we employ two-way clustering by judge and case when we present placebo regressions (the effect of Manne training on the previous case of the Judge strengthens when we two-way cluster).

In a second analysis, we use our data on the topics of each case. In this part, $\mathrm{a}_{i-\ell}^{j}$ includes an additional treatment indicator for whether there is an economics judge on the previous case on the current case's same legal topic. ${ }^{21}$ Here, we identify economics phrases that move within topic separately from those that move across topics. Note that topics are not randomly ordered, but judges are randomly assigned. We control for unobservables related to the order of topics by including controls for the order of cases within the Circuit. We also look at one subset of this by examining the movement of ideas from regulation cases to criminal cases.

\subsection{Memetic Effects}

We examine which phrases travel within topics and those that travel across topics, both within judge. We first present results using the same index of law-and-economics vocabulary coming from Robert Ellickson's (2000) analysis of trends in legal scholarship as described above. In the Appendix, we present results on particular key phrases "capital", "deterrence" and "law and economics."

Table 9 reports the results with this outcome. In general, we see that in response to sitting with a Manne judge, the Ellickson index transmits from one case to the next.

The index is an average of 9 words, so one would multiply by 9 to interpret the coefficients in terms of frequency of individual words. For every 100 cases, if there is an economics-trained judge, there are 5 cases that use a word from the Ellickson index (Column 2). For every 100 cases where the previous case had an economics-trained judge, 3.8 cases use a word from the Ellickson index (Column 3). The same effect size is observed for the previous case on the same topic with an economics-trained judge. However, two cases later, the effect is only observed if it is the same topic: 6.9 cases out of 100 will have a word from the Ellickson index (on average). Again, no lead effects

\footnotetext{
${ }^{21}$ We use the 2-digit hand-labeled topic in the $100 \%$ data.
} 
Table 9: Manne Co-Panelist Impact on use of Ellickson Law-Econ Language Index

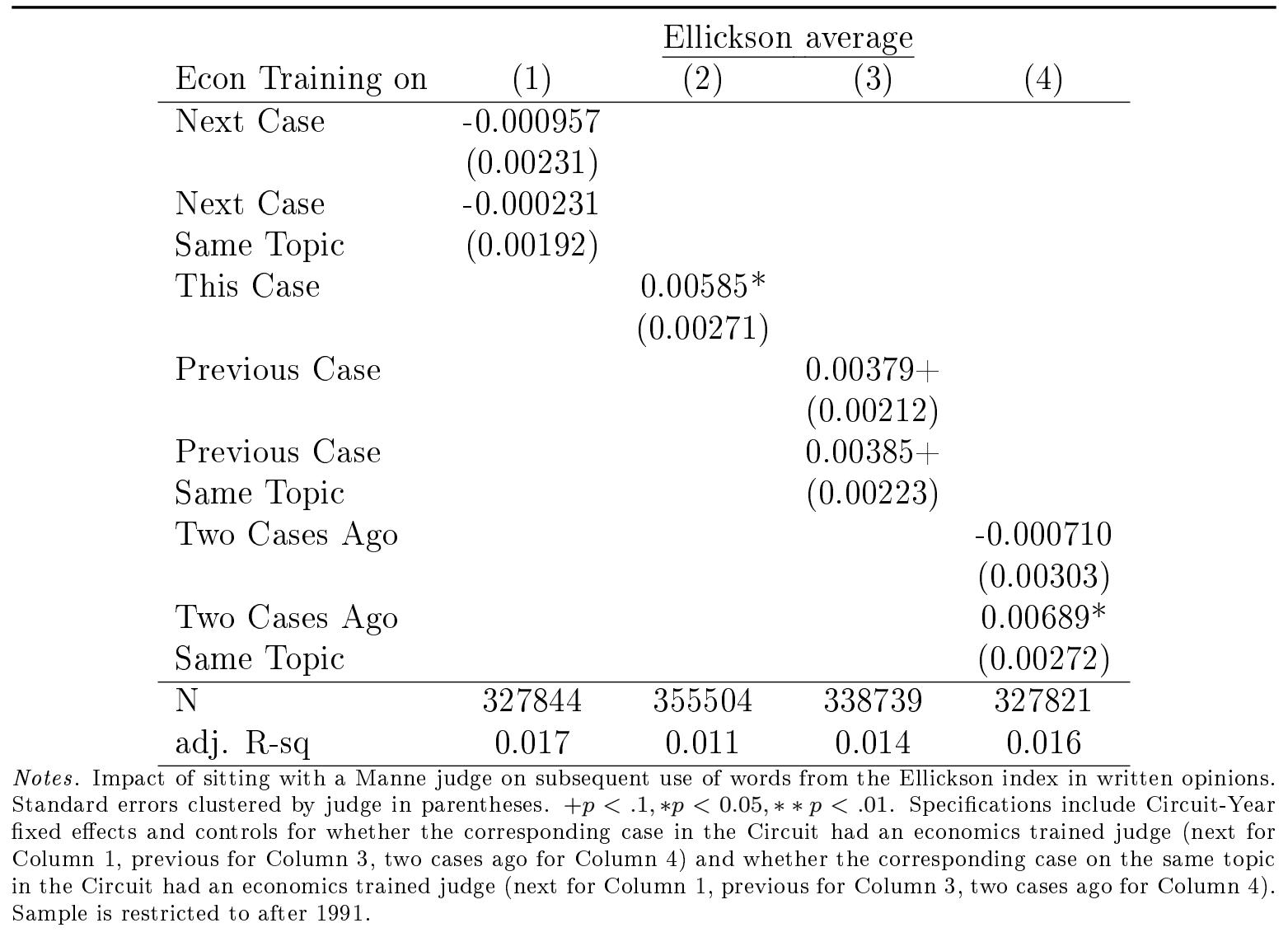

are observed (Column) and the standard errors are similar in size.

Next, we show the effect of exposure to a Manne judge appears specifically for nonManne judges. We also see that Manne attendance increases use of economics language for Manne judges across both economics and non-economics cases.

Economics clearly diffuses via the judicial panels, but we further examine whether the form of the diffusion depends on the topic of the case. Previously, we saw effects on regulation cases and crime cases. Economic thinking around incentives, while naturally deployed in consider regulatory cases, may influence subsequent thinking on criminal cases, and we now look at the diffusion of ideas between these legal topics. Table 11 restricts the sample to cases where a criminal case follows a regulation case, or vice versa. Again, the outcome is transmission of Ellickson Index language between cases.

The column numbers $(1,0,-1,-2,-3,-4)$ give the relative sequence of the treated case (where a Manne judge is sitting). So to start, Column 0 is the present case. 
Table 10: Manne Co-Panelist Impact on non-Manne Judges

\begin{tabular}{|c|c|c|c|c|}
\hline & \multicolumn{4}{|c|}{ Ellickson Average } \\
\hline & & $(1)$ & $(2)$ & \\
\hline & Econ Case & $0.0300^{* *}$ & $0.0294^{* *}$ & \\
\hline & & $(0.00524)$ & $(0.00249)$ & \\
\hline & Post-Manne & $0.0141^{*}$ & & \\
\hline & & $(0.00630)$ & & \\
\hline & Econ Case ${ }^{*}$ & 0.00170 & & \\
\hline & Post-Manne & $(0.00919)$ & & \\
\hline & Econ Training on & -0.00559 & $0.00513+$ & \\
\hline & Previous Case & $(0.0106)$ & $(0.00292)$ & \\
\hline & $\mathrm{N}$ & 143144 & 486673 & \\
\hline & adj. R-sq & 0.042 & 0.042 & \\
\hline & Circuit-Year FE & $\mathrm{X}$ & $\mathrm{X}$ & \\
\hline & Judge FE & $\mathrm{X}$ & $\mathrm{X}$ & \\
\hline & Sample & Ever-Manne & Never-Manne & \\
\hline
\end{tabular}

Column 1 is the next case, so assignment of a Manne judge in the future should not have an impact today. Columns $-1,-2,-3$, and -4 respectively give the previous, second previous, third previous, and fourth previous cases in the sequence.

In the top panel, the current case is criminal, and the treated case is a regulation case. In the bottom panel, the current case is regulation, and the treated case is criminal. First, we can see in the bottom panel that regardless of the sequence, there is no apparent transmission of economics ideas from criminal cases into regulation cases. In the top panel, however, we see that there is a strong and persistent impact of sitting with a Manne judge on a regulation case, when the outcome case is on crime. This substantiates a mechanism for the spread of incentives reasoning into criminal law.

To summarize: Manne economics trained judges are influential, ${ }^{22}$ and economics language is contagious. Judges who sit with economics-trained judges start to use more economics language, consistent with a learning effect. Economics language tends to cross topic boundaries, and that effect is stronger when moving from economic cases (regulation) to non-economic cases (crime). The next table shows a peer impact on

\footnotetext{
${ }^{22}$ In the online appendix, we also report results that Manne-trained judges are cited more often than non-Manne judges.
} 
Table 11: Ellickson Index Diffusion Between Regulation and Crime Cases

\begin{tabular}{|c|c|c|c|c|c|c|}
\hline Econ Training on & {$[\mathrm{N}]=(1)$} & $(0)$ & $\frac{\text { Ellicl }}{(-1)}$ & $\begin{array}{c}\text { son Average } \\
(-2)\end{array}$ & $(-3)$ & $(-4)$ \\
\hline \multicolumn{7}{|c|}{ Current Case is Criminal, Previous [N] Case is Regulation } \\
\hline$[\mathrm{N}]$ cases later & $\begin{array}{c}0.0119 \\
(0.0114)\end{array}$ & $\begin{array}{l}- \\
-\end{array}$ & $\begin{array}{c}0.0304^{* *} \\
(0.0103)\end{array}$ & $\begin{array}{c}-0.00639 \\
(0.0146)\end{array}$ & $\begin{array}{c}0.0180+ \\
(0.00951)\end{array}$ & $\begin{array}{c}0.0253^{*} \\
(0.0117)\end{array}$ \\
\hline $\mathrm{N}$ & 17314 & - & 17238 & 17714 & 17658 & 17723 \\
\hline adj. R-sq & 0.035 & - & 0.314 & 0.119 & 0.078 & 0.209 \\
\hline \multicolumn{7}{|c|}{ Current Case is Regulation, Previous [N] Case is Criminal } \\
\hline$[\mathrm{N}]$ cases later & $\begin{array}{c}-0.00277 \\
(0.00981)\end{array}$ & $\begin{array}{l}- \\
- \\
\end{array}$ & $\begin{array}{r}-0.00371 \\
(0.0136)\end{array}$ & $\begin{array}{c}0.0110 \\
(0.00990)\end{array}$ & $\begin{array}{c}-0.0383 \\
(0.0242)\end{array}$ & $\begin{array}{c}-0.0243 \\
(0.0246)\end{array}$ \\
\hline $\mathrm{N}$ & 17176 & - & 17355 & 17552 & 17731 & 17636 \\
\hline adj. R-sq & 0.042 & - & 0.080 & 0.034 & 0.047 & 0.072 \\
\hline
\end{tabular}

Notes. Impact of sitting with Manne judge on the Ellickson Average, separated out by topic of previous and current case. Specifications include Circuit $\mathrm{x}$ Year fixed effects and controls for whether the previous [Nth] case in the Circuit had an economics trained judge. Sample is restricted to after 1991.

decisions in environmental and labor agencies. In the appendix we report a series of robustness checks of the main findings, where we compare never-attenders with everattenders prior to the program beginning, when one might expect a pent-up demand to be reflected in significant differences. We also report analyses using a change in instructors, namely Milton Friedman, and compare Friedman trainees vs. non-Friedman trainees.

\section{Discussion and Conclusion}

Economics has substantially affected the federal judiciary. We see economics language in academic articles being adopted in judicial opinions. We see economics trained judges changing their decisions and impacting their peers. We see economics language traveling from judge to judge and across legal topics.

Economics-trained judges significantly impact U.S. judicial outcomes. They render conservative votes and verdicts, are against regulation and criminal appeals, and mete harsher criminal sentences and deterrence reasoning. When ideas move from economics into law, ideas have consequences. 
Table 12: Manne Co-Panelist Impact on non-Manne Judges

\begin{tabular}{ccccccc}
\hline & \multicolumn{5}{c}{ Voting Against Environmental or Labor Agency [N] cases later } \\
\cline { 2 - 7 } Econ Training on & {$[\mathrm{N}]=(-1)$} & $(0)$ & $(1)$ & $(2)$ & $(3)$ & $(4)$ \\
\hline$[\mathrm{N}]$ cases later & -0.00338 & - & -0.00438 & $0.0192^{*}$ & 0.00929 & -0.00420 \\
& $(0.0111)$ & - & $(0.0100)$ & $(0.00887)$ & $(0.00995)$ & $(0.0101)$ \\
Circuit-Year FE & $\mathrm{Y}$ & - & $\mathrm{Y}$ & $\mathrm{Y}$ & $\mathrm{Y}$ & $\mathrm{Y}$ \\
\hline$[\mathrm{N}]$ cases later & -0.00811 & -0.00544 & $0.0236^{*}$ & 0.0113 & -0.0145 \\
& $(0.0160)$ & & $(0.0136)$ & $(0.0120)$ & $(0.0128)$ & $(0.0139)$ \\
Circuit-Year FE & $\mathrm{Y}$ & - & $\mathrm{Y}$ & $\mathrm{Y}$ & $\mathrm{Y}$ & $\mathrm{Y}$ \\
Judge FE & $\mathrm{Y}$ & - & $\mathrm{Y}$ & $\mathrm{Y}$ & $\mathrm{Y}$ & $\mathrm{Y}$ \\
\hline Circuit Order & $\mathrm{Y}$ & - & $\mathrm{Y}$ & $\mathrm{Y}$ & $\mathrm{Y}$ & $\mathrm{Y}$ \\
Order within & Judge & - & Judge & Judge & Judge & Judge \\
Cluster & Judge & - & Judge & Judge & Judge & Judge \\
Notes. Impact of sitting with a Manne judge on voting against EPA or NLRB. Standard errors clustered by judge in \\
parentheses. $+p<.1, * p<0.05, * * p<.01$. Specifications include Circuit-Year fixed effects and, in panel B, judge fixed \\
effects.
\end{tabular}

Economics likely changed how judges perceived the consequences of their decisions. If you teach judges that markets work, they deregulate government. If you teach judges that deterrence works, they become harsher to criminal defendants. Economics training focusing on efficiency may have crowded out other constitutional theories of interpretation. Economics training accounts for a substantial portion of the conservative shift in the federal judiciary since 1976.

It seems that the instruction in the Manne program, although there was an effort for balance (Butler, 1999), overall had a conservative impact, and not in just economicsrelated areas of the law such as regulation. Normative assessment of the conservative impact likely depends on views about the efficiency of the pre-LEC legal apparatus, and we take no stand on this. To be sure, the 1970s law and economics research applied only the simplest price theory arguments, which may have rendered conservative conclusions.

We also present a framework that leverages the exogenous seating network of judicial panels and exogenous case topics to examine how ideas diffuse. We find that Manne-trained judges influence other judges on the same panel, and this effect operates via transmission from regulatory cases to criminal ones. This work is related to a broader understanding of the cultural and ideological roots of social preferences. Economics training makes more salient certain criteria, like deterrence and incentives, when deciding whether and how much to punish. In ongoing work, we also see greater 
consequentialist reasoning over time and in dissents and that Manne judges increase their citations and dissents after training.

This research opens the door to many new questions. In parallel work we are looking at the impacts of originalist jurisprudence. Another potentially important source of conservative jurisprudence is textualism. Future work could try to score cases by how much they tried to use the plain meaning (rather than the inferred intent) of laws. We are also looking at unpacking the mechanisms of persuasion by interacting exogenous characteristics of the panel with exposure to Manne judges or the subsequent panels, to see if transmission occurs more in like-minded groups or during forment (using predictors of citation impact, reversals, or dissent based on the text of the District Court opinions). We are also exploring the use of word embeddings to identity implicit (or explicit) associations to see if economics affects stereotypes or simply activates the use of stereotypes. We are using the citation network to identify the geneology of ideas, that is, capture the phrases and legal precedents that push across the network. Broadly, if law and economics induced a paradigm shift, can we measure it and compare it to other paradigm changes in law?

More generally, one can analyze the impacts of various sources of legal thought. Just as law and economics is known to have a conservative bias, so is Critical Legal Studies known to have a liberal bias. One could use the language and/or other features of judicial decisions to score judges and decisions by their relation to various schools of legal thought and philosophy. 


\section{References}

Alesina, A. and Fuchs-Schündeln, N. (2007). Good-bye lenin (or not?): The effect of communism on people's preferences. The American Economic Review, 97(4):15071528.

Arora, S., Liang, Y., and Ma, T. (2017). A simple but tough-to-beat baseline for sentence embeddings.

Ash, E. (2016). The political economy of tax laws in the u.s. states. Technical report.

Ash, E. and Chen, D. L. (2017). Religious freedoms, church-state separation, and religiosity: Evidence from randomly assigned judges.

Ash, E. and MacLeod, W. B. (2015). Intrinsic motivation in public service: Theory and evidence from state supreme courts. Journal of Law and Economics.

Ash, E., Morelli, M., and Van Weelden, R. (2017). Elections and divisiveness: Theory and evidence. Journal of Politics.

Baye, M. R. and Wright, J. D. (2011). Is antitrust too complicated for generalist judges? the impact of economic complexity and judicial training on appeals. The Journal of Law and Economics, 54(1):1-24.

Becker, G. S. (1968). Crime and punishment: An economic approach. Journal of Political Economy, 76(2):169-217.

Belloni, A., Chen, D. L., Chernozhukov, V., and Hansen, C. (2012). Sparse models and methods for optimal instruments with an application to eminent domain. Econometrica, 80(6):2369-2429.

Berdejo, C. and Chen, D. L. (2016). Electoral Cycles Among U.S. Courts of Appeals Judges. Technical report.

Besley, T. and Coate, S. (1997). An economic model of representative democracy. The Quarterly Journal of Economics, pages 85-114.

Blumm, M. C. (1995). The end of environmental law? libertarian property, natural law, and the just compensation clause in the federal circuit. Environmental Law, pages $171-198$. 
Bordalo, P., Gennaioli, N., and Shleifer, A. (2015). Salience theory of judicial decisions. The Journal of Legal Studies, 44(S1):S7-S33.

Boyd, C., Epstein, L., and Martin, A. D. (2010). Untangling the causal effects of sex on judging. American Journal of Political Science, 54(2):389-411.

Butler, H. N. (1999). Manne programs in economics for federal judges, the. Case W. Res. L. Rev., 50:351.

Calabresi, G. (1970). The Costs of Accidents: A Legal and Economic Analysis. Yale University Press.

Cameron, C. M. (1993). New Avenues for Modeling Judicial Politics. In Conference on the Political Economy of Public Law, Rochester, NY. W. Allen Wallis Institute of Political Economy, University of Rochester.

Cantoni, D., Chen, Y., Yang, D. Y., Yuchtman, N., and Zhang, Y. J. (2014). Curriculum and Ideology.

Chen, D., Halberstam, Y., and Yu, A. C. L. (2016). Perceived Masculinity Predicts United States Supreme Court Outcomes. PLOS-ONE, revise and resubmit.

Chen, D. L. (2014). This morning's breakfast, last night's game: Detecting extraneous factors in judging. Working paper, ETH Zurich.

Chen, D. L. (2016). Priming Ideology: Why Presidential Elections Affect U.S. Courts of Appeals Judges. Technical report.

Chen, D. L., Moskowitz, T. J., and Shue, K. (2015). Decision-Making Under the Gambler's Fallacy: Evidence from Asylum Judges, Loan Officers, and Baseball Umpires. Working paper, ETH Zurich.

Chen, D. L. and Sethi, J. (2011). Insiders and outsiders: Does forbidding sexual harassment exacerbate gender inequality? Working paper, University of Chicago.

Chen, D. L. and Yeh, S. (2014). Growth Under the Shadow of Expropriation? The Economic Impacts of Eminent Domain. Working paper, ETH Zurich and George Mason University.

Cullen, F. T. and Gendreau, P. (2001). From nothing works to what works: Changing professional ideology in the 21st century. The Prison Journal, 81(3):313-338. 
Dahl, G. B., Kostøl, A. R., and Mogstad, M. (2014). Family Welfare Cultures. Quarterly Journal of Economics, 129(4):1711-1752.

Ellickson, R. C. (2000). Trends in legal scholarship: A statistical study. The Journal of Legal Studies, 29(S1):517-543.

Epstein, R. A. (1983). A common law for labor relations: A critique of the new deal labor legislation. The Yale Law Journal, 92(8):1357-1407.

Falk, A. and Tirole, J. (2016). Narratives, imperatives and moral reasoning.

Fisman, R., Kariv, S., and Markovits, D. (2009). Exposure to ideology and distributional preferences. Working paper, Yale Law School.

Fuchs-Schündeln, N. and Masella, P. (2016). Long-lasting effects of socialist education. Review of Economics and Statistics, 98(3):428-441.

Gennaioli, N. and Shleifer, A. (2007). The evolution of common law. The Journal of Political Economy, 115(1):43-68.

Gentzkow, M., Kelly, B. T., and Taddy, M. (2017a). Text as data. Technical report, National Bureau of Economic Research.

Gentzkow, M., Shapiro, J. M., and Taddy, M. (2017b). Measuring Polarization in High-Dimensional Data: Method and Application to Congressional Speech.

Ginsburg, D. H. (2010). Originalism and economic analysis: Two case studies of consistency and coherence in supreme court decision making. Harv. JL \& Pub. Pol'y, $33: 217$.

Goetz, C. J. and Scott, R. E. (1977). Liquidated damages, penalties and just compensation principle - some notes on an enforcement model and a theory of efficient breach. Columbia Law Review, 77(4):554-594. Article.

Haire, S. B., Songer, D. R., and Lindquist, S. A. (2003). Appellate court supervision in the federal judiciary: A hierarchical perspective. Law \& Society Review, 37(1):143168.

Harcourt, B. E. (2011). The illusion of free markets. Harvard University Press. 
Hirschman, A. O. (1978). Exit, voice, and the state. World Politics: A Quarterly Journal of International Relations, pages 90-107.

Hirschman, A. O. (1991). The rhetoric of reaction. Harvard University Press.

Jelveh, Z., Kogut, B., and Naidu, S. (2015). Political language in economics.

Jensen, J., Naidu, S., Kaplan, E., and Wilse-Samson, L. (2012). Political polarization and the dynamics of political language: Evidence from 130 years of partisan speech [with comments and discussion]. Brookings Papers on Economic Activity, pages 1-81.

Kleiman, M. (2009). When brute force fails: How to have less crime and less punishment. Princeton University Press.

Kling, J. R. (2006). Incarceration length, employment, and earnings. The American Economic Review, 96(3):863-876.

Kornhauser, L. A. (1999). Judicial organization and administration. In Sanchirico, C. W., editor, Encyclopedia of Law and Economics, volume 5, chapter 11, pages $27-44$.

Kốszegi, B. and Szeidl, A. (2013). A model of focusing in economic choice. The Quarterly Journal of Economics, 128(1):53-104.

Maestas, N., Mullen, K. J., and Strand, A. (2013). Does disability insurance receipt discourage work? using examiner assignment to estimate causal effects of ssdi receipt. American Economic Review, 103(5):1797-1829.

Martinson, R. (1974). What works?-questions and answers about prison reform. The public interest, (35):22.

Mueller-Smith, M. (2014). The criminal and labor market impacts of incarceration: Identifying mechanisms and estimating household spillovers. Working paper, Columbia University.

Nagin, D. S. (1998). Criminal deterrence research at the outset of the twenty-first century. Crime and justice, pages 1-42.

Petersilia, J. and Turner, S. (1993). Intensive probation and parole. Crime and justice, pages 281-335. 
Posner, R. A. (1973). An economic approach to legal procedure and judicial administration. The Journal of Legal Studies, 2(2):399-458.

Posner, R. A. (1984). Some economics of labor law. The University of Chicago Law Review, 51(4):988-1011.

Posner, R. A. (1987). The law and economics movement. The American Economic Review, 77(2):pp.1-13.

Posner, R. A. (1995). Judges' writing styles (and do they matter?). The University of Chicago Law Review, 62(4):1421-1449.

Rehavi, M. M. and Starr, S. B. (2014). Racial disparity in federal criminal sentences. Journal of Political Economy, 122(6):1320-1354.

Seabright, P. (1996). Accountability and decentralisation in government: An incomplete contracts model. European Economic Review, 40(1):61-89.

Stephenson, M. C. (2009). Legal realism for economists. The Journal of Economic Perspectives, 23(2):pp.191-211.

Sunstein, C. R., Schkade, D., Ellman, L. M., and Sawicki, A. (2006). Are Judges Political?: An Empirical Analysis of the Federal Judiciary. Brookings Institution Press.

Teles, S. M. (2012). The rise of the conservative legal movement: The battle for control of the law. Princeton University Press.

van Winden, F. and Ash, E. (2012). On the behavioral economics of crime. Review of Law Gamp; Economics, 8:181-213.

Yang, C. S. (2014). Have Interjudge Sentencing Disparities Increased in an Advisory Guidelines Regime? Evidence From Booker. New York University Law Review, 89(4):1268-1342. 
Figure 11: Distribution of Cases Over Time

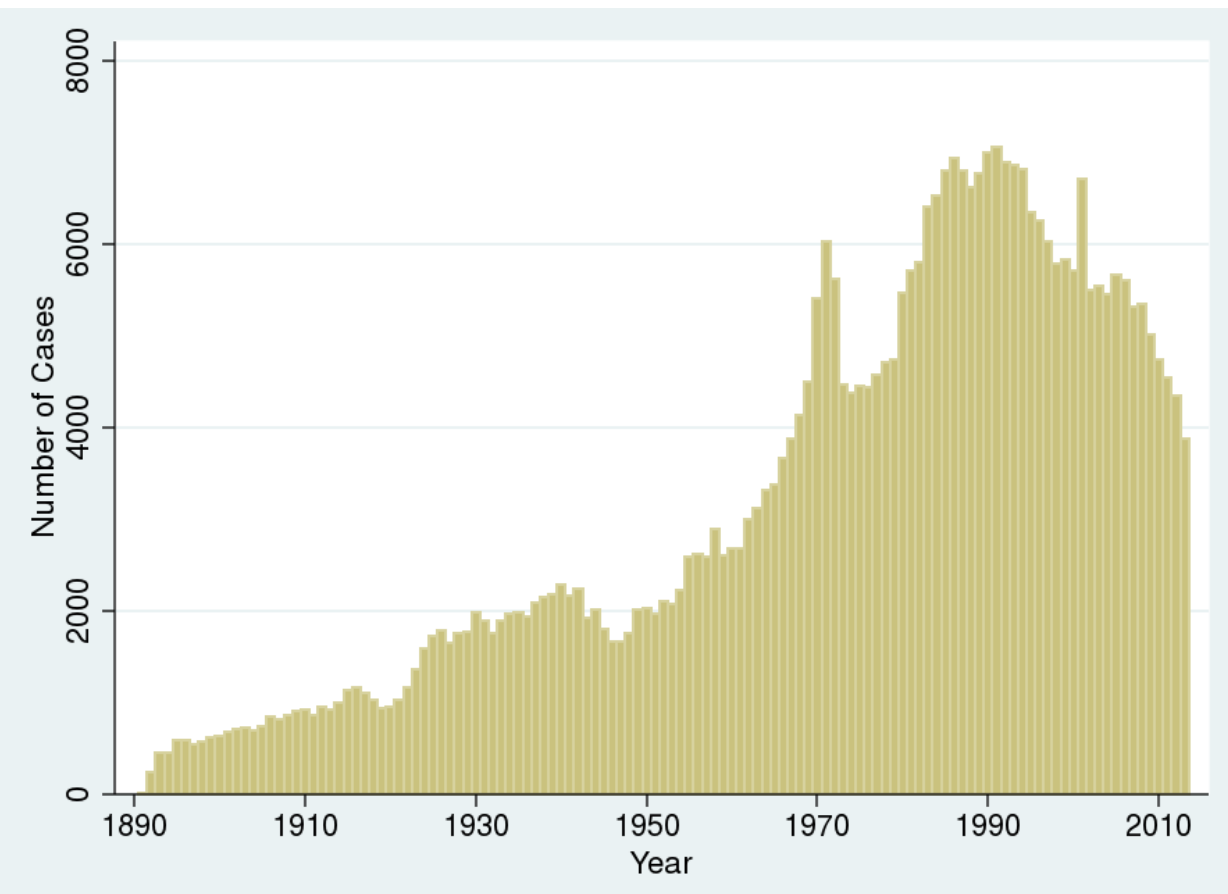

\section{A Data Setting}

There are three layers in the U.S. Federal Court system: the local level (District Court), intermediate level (Circuit Court), and national level (Supreme Court). Judges are appointed by the U.S. President and confirmed by the U.S. Senate. They are responsible for the adjudication of disputes involving common law and interpretation of federal statutes. Their decisions establish precedent for adjudication in future cases in the same court and in lower courts within its geographic boundaries. The 12 U.S. Circuit Courts (Courts of Appeals) take cases appealed from the 94 District Courts. The Circuit Courts have no juries. Each Circuit Court presides over 3-9 states. The vast majority $(98 \%)$ of their decisions are final. ${ }^{23}$ Judges have life tenure.

Our key data set is the set of judicial decisions published by the United States Circuits of Appeal for the years 1891 through 2013. The cases were manually collected and cross-checked against other existing datasets. Figure 11 shows the distribution of cases over the years in our sample. We have the set of judges working on the three-judge

\footnotetext{
${ }^{23}$ In the remaining $2 \%$ that are appealed to the Supreme Court, $30 \%$ are affirmed.
} 
Table 13: Distribution of High-Level Case Topics

\begin{tabular}{lcc}
\hline Songer Topic & Freq. & Percent \\
\cline { 2 - 3 } Economics & 332,553 & 29.69 \\
Due Process & 259,845 & 23.20 \\
Criminal Appeal & 250,281 & 22.34 \\
Miscellaneous & 149,322 & 13.33 \\
Civil Rights & 67,350 & 6.01 \\
Labor & 54,681 & 4.88 \\
First Amendment & 5,268 & 0.47 \\
Privacy & 927 & 0.08 \\
\hline Total & $1,120,227$ & 100.0
\end{tabular}

panel for each case. Of these judges, we have the authoring judge, as well as whether either of the other judges wrote a dissenting opinion.

In Table 13 is a 1-digit coarse categorization from the $5 \%$ sample (also referred to as the Songer Database). A substantial portion is criminal law (22\%) and economicsrelated $(30 \%)$.

The final set of data that we use is the set of judge biographical characteristics from the Appeals Court Attribute Data, ${ }^{24}$ Federal Judicial Center, and previous data collection. ${ }^{25}$ These data help control for other shifters of ideology. We constructed dummy indicators for whether the judge was female, non-white, black, Jewish, catholic, protestant, evangelical, mainline, non-religiously affiliated, whether the judge obtained a BA from within the state, attended a public university for college, had a graduate law degree (LLM or SJD), had any prior government experience, was a former magistrate judge, former bankruptcy judge, former law professor, former deputy or assistant district/county/city attorney, former Assistant U.S. Attorney, former U.S. Attorney, former Attorney-General, former Solicitor-General, former state high court judge, former state lower court judge, formerly in the state house, formerly in state senate, formerly in the U.S. House of Representatives, formerly a U.S. Senator, formerly in private practice, former mayor, former local/municipal court judge, formerly worked in the Solicitor-General's office, former governor, former District/County/City Attorney, former Congressional counsel, formerly in city council, born in the 1910s, 1920s, 1930s, 1940s, or 1950s, whether government (Congress and president) was unified or divided

\footnotetext{
${ }^{24} \mathrm{http}: / /$ www.cas.sc.edu/poli/juri/attributes.html

${ }^{25}$ Missing data was filled in by searching transcripts of Congressional confirmation hearings and other official or news publications on Lexis (Chen and Yeh 2014).
} 
Table 14: Distribution of Case Topics

\begin{tabular}{lcc|lcc}
\hline Songer Topic & Freq. & Percent & Detailed Topic (partial list) & Freq. & Percent \\
\hline Economics & 332,553 & 29.69 & Criminal Law & 246,012 & 22.27 \\
Due Process & 259,845 & 23.20 & Civil Procedure & 194,391 & 17.6 \\
Criminal Appeal & 250,281 & 22.34 & Administrative Law & 51,900 & 4.7 \\
Miscellaneous & 149,322 & 13.33 & Tax \& Accounting & 46,404 & 4.2 \\
Civil Rights & 67,350 & 6.01 & Bankruptcy Law & 40,773 & 3.69 \\
Labor & 54,681 & 4.88 & Constitutional Law & 34,575 & 3.13 \\
First Amendment & 5,268 & 0.47 & Habeas Corpus & 33,429 & 3.03 \\
Privacy & 927 & 0.08 & Contracts & 32,700 & 2.96 \\
\hline Total & $1,120,227$ & 100.0 & .. and 86 additional topics & & \\
\hline
\end{tabular}

at the time of appointment, and whether judge and appointing president were of the same or different political parties.

\section{A.1 Balance Checks on Manne Attendance}

Columns 1 and 3 include all control variables. Columns 2 and 4 include those selected by elastic net with regularization parameters chosen by cross-validation.

\section{B More Background on Manne Program}

This appendix provides more background from archival research about the Manne Program. The public perception of the Manne Program was a beach on the south of Miami for a few weeks funded by large corporate donors. A Washington Post reporter writes:

105 corporate contributors are almost always before a federal judge somewhere, often in antitrust, regulatory, or affirmative-action cases... probably all federal judges face some possibility [of having a contributor as litigant]. ${ }^{26}$

\footnotetext{
26“"Big Corporations Bankroll Seminars For U.S. Judges," Washington Post, 20 Jan 1980. The list of donors included Abbott Laboratories, Alcoa, Amoco, Bristol-Myers, Campbell Soup, Chase Manhattan Bank, Chevron, du Pont, Kodak, Exxon, Ford Motor Company, General Electric, General Motors, Gerber Baby Foods, Getty Oil, Hoffmann-La Roche, Eli Lilly, Merrill Lynch, Mobil, Pennzoil, Pfizer, Procter \& Gamble, Raytheon, Schering-Plough, Sears Roebuck, Shell, Southwestern Bell, Sun Company, Texaco, Unilever, Union Oil, Upjohn, US Steel, Winn-Dixie, Xerox, among many others.
} 
Table 15: Covariate Balance, Circuit Courts

\begin{tabular}{|c|c|c|c|c|c|c|c|c|c|}
\hline & \multicolumn{2}{|c|}{ Ever Attend } & \multicolumn{2}{|c|}{ Year of Attendance } & & \multicolumn{2}{|c|}{ Ever Attend } & \multicolumn{2}{|c|}{ Year of Attendance } \\
\hline & (1) & (2) & (3) & (4) & & (1 cont.) & (2 cont.) & (3 cont.) & (4 cont.) \\
\hline \multirow[t]{2}{*}{ Unified Appoint } & -0.0237 & -0.0386 & 1.392 & & Governor & -0.0156 & & 0 & \\
\hline & $(0.0231)$ & $(0.0221)$ & $(2.360)$ & & & $(0.0711)$ & & $()$. & \\
\hline \multirow[t]{2}{*}{ Cross-Party Appoint } & -0.0226 & & 3.857 & & District Attorney & -0.00409 & & -0.890 & \\
\hline & $(0.0407)$ & & $(2.395)$ & & & $(0.0406)$ & & $(1.751)$ & \\
\hline \multirow[t]{2}{*}{ Republican } & $0.0508 * *$ & $0.0379 *$ & 1.768 & & City Council & 0.0548 & & -1.751 & \\
\hline & $(0.0191)$ & $(0.0186)$ & $(2.303)$ & & & $(0.0948)$ & & $(2.295)$ & \\
\hline \multirow[t]{2}{*}{ U.S. Attorney } & 0.0166 & & -1.481 & & County Comm & -0.0946 & & $11.17 * *$ & $10.29 * *$ \\
\hline & $(0.0413)$ & & $(1.703)$ & & & $(0.0697)$ & & $(2.340)$ & $(0.797)$ \\
\hline \multirow[t]{2}{*}{ State Senator } & 0.0439 & & -1.693 & & Assit U.S. Atty & 0.00629 & & 0.914 & \\
\hline & $(0.0814)$ & & $(1.351)$ & & & $(0.0348)$ & & $(2.295)$ & \\
\hline \multirow[t]{2}{*}{ State Lower Ct } & -0.0287 & & -1.609 & & Atty General & -0.104 & & 0 & \\
\hline & $(0.0310)$ & & $(1.384)$ & & & $(0.118)$ & & $()$. & \\
\hline \multirow[t]{2}{*}{ State Supr Court } & 0.0469 & & 2.775 & & Asst Dist Atty & $0.109^{*}$ & $0.109^{*}$ & -0.803 & \\
\hline & $(0.0372)$ & & $(1.473)$ & & & $(0.0530)$ & $(0.0482)$ & $(1.677)$ & \\
\hline \multirow[t]{2}{*}{ State House } & 0.0192 & & 1.223 & & Any Govt Exper & 0.00160 & & -1.534 & \\
\hline & $(0.0427)$ & & (1.309) & & & $(0.0394)$ & & $(2.252)$ & \\
\hline \multirow[t]{2}{*}{ Solicit Gen Office } & $-0.144 * *$ & $-0.162 *$ & 0 & & Black & 0.0469 & & 1.270 & \\
\hline & $(0.0536)$ & $(0.0664)$ & $()$. & & & $(0.0583)$ & & $(1.543)$ & \\
\hline \multirow[t]{2}{*}{ Solicitor General } & 0.176 & 0.193 & 1.950 & & Cohort: $1910 \mathrm{~s}$ & $0.108 * *$ & & 0 & $-8.496 * *$ \\
\hline & $(0.126)$ & $(0.133)$ & $(2.753)$ & & & $(0.0298)$ & & $()$. & $(1.265)$ \\
\hline \multirow[t]{2}{*}{ U.S. Senator } & 0.0136 & & $4.779 * *$ & & Cohort: $1920 \mathrm{~s}$ & $0.308 * *$ & $0.267 * *$ & $3.769 *$ & $-4.853 * *$ \\
\hline & $(0.0634)$ & & $(1.493)$ & & & $(0.0508)$ & $(0.0499)$ & $(1.440)$ & $(1.403)$ \\
\hline \multirow[t]{2}{*}{ State Atty General } & -0.00437 & & -0.613 & & Cohort: 1930s & $0.249 * *$ & $0.205 * *$ & $8.038 * *$ & \\
\hline & $(0.0366)$ & & $(1.911)$ & & & $(0.0498)$ & $(0.0482)$ & $(1.775)$ & \\
\hline \multirow[t]{2}{*}{ Private Practice } & 0.0544 & & -2.576 & & Cohort: 1940s & $0.126 * *$ & $0.0841 *$ & $14.48^{* *}$ & $5.504 * *$ \\
\hline & $(0.0435)$ & & $(2.891)$ & & & $(0.0389)$ & $(0.0391)$ & $(1.852)$ & $(1.525)$ \\
\hline \multirow[t]{2}{*}{ Mayor } & 0.0783 & & -4.548 & & Cohort: $1950 \mathrm{~s}$ & 0.0229 & & $17.28 * *$ & \\
\hline & $(0.0959)$ & & $(2.919)$ & & & $(0.0249)$ & & $(3.250)$ & \\
\hline \multirow[t]{2}{*}{ Local Court } & 0.0696 & 0.0515 & $3.149 *$ & 3.112 & Bnktcy Judge & 0.135 & 0.140 & -2.896 & \\
\hline & $(0.0543)$ & $(0.0522)$ & $(1.575)$ & $(2.028)$ & & $(0.183)$ & $(0.182)$ & $(2.734)$ & \\
\hline \multirow[t]{2}{*}{ U.S. House } & -0.0367 & & 3.087 & & Magistr Judge & $-0.166 * *$ & $-0.174 * *$ & 0 & \\
\hline & $(0.0531)$ & & $(3.077)$ & & & $(0.0556)$ & $(0.0483)$ & $()$. & \\
\hline All Variables & $x$ & & $x$ & & & $x$ & & $x$ & \\
\hline Post Elastic Net & & $x$ & & $x$ & & & $x$ & & $x$ \\
\hline $\mathrm{N}$ & 699 & 699 & 85 & 85 & & 699 & 699 & 85 & 85 \\
\hline adj. R-sq & 0.124 & 0.129 & 0.464 & 0.497 & & 0.124 & 0.129 & 0.464 & 0.497 \\
\hline
\end{tabular}

Notes. Regression of Manne training on all covariates (1) and (3) and elastic-net-selected covariates (2) and (4). Robust standard errors clustered at the judge level in parentheses. $* p<0.05, * * p<.01$. Data collapsed by judge. A variable that mentions a position means the judge had prior experience in that position. Codebook for variables available in online appendix. 
Table 16: Covariate Balance, District Court Judges

\begin{tabular}{|c|c|c|c|c|c|c|c|c|c|}
\hline & \multicolumn{2}{|c|}{ Ever Attend } & \multicolumn{2}{|c|}{ Year of Attendance } & & \multicolumn{2}{|c|}{ Ever Attend } & \multicolumn{2}{|c|}{ Year of Attendance } \\
\hline & (1) & (2) & (3) & (4) & & (1 cont.) & (2 cont.) & (3 cont.) & (4 cont.) \\
\hline \multirow[t]{2}{*}{ Unified Appoint } & -0.00905 & -0.00925 & -3.567 & & Governor & 0.0325 & & $-5.145 * *$ & $-4.824 * *$ \\
\hline & $(0.0111)$ & $(0.0106)$ & $(2.923)$ & & & $(0.0668)$ & & (1.099) & $(1.066)$ \\
\hline \multirow[t]{2}{*}{ Cross-Party Appoint } & -0.0330 & & -0.947 & -1.121 & District Attorney & -0.00458 & -0.0104 & 0.122 & \\
\hline & $(0.0293)$ & & $(1.168)$ & $(1.092)$ & & $(0.0174)$ & $(0.0170)$ & $(0.836)$ & \\
\hline \multirow[t]{2}{*}{ Republican } & $0.0398 * *$ & $0.0393 * *$ & -3.875 & & City Council & $-0.0933^{*}$ & $-0.0848 *$ & $-4.080 *$ & \\
\hline & $(0.0104)$ & $(0.00989)$ & $(2.928)$ & & & $(0.0408)$ & $(0.0387)$ & $(1.702)$ & \\
\hline \multirow[t]{2}{*}{ U.S. Attorney } & -0.00916 & & -0.951 & -1.049 & County Comm & -0.0377 & & 1.212 & \\
\hline & $(0.0225)$ & & $(0.728)$ & $(0.631)$ & & $(0.0331)$ & & $(1.453)$ & \\
\hline \multirow[t]{2}{*}{ State Senator } & 0.0149 & & $-2.168 *$ & $-2.155^{*}$ & Assit U.S. Atty & $0.0432 *$ & $0.0426 *$ & -0.00997 & \\
\hline & $(0.0313)$ & & $(0.951)$ & $(0.877)$ & & $(0.0206)$ & $(0.0190)$ & $(0.681)$ & \\
\hline \multirow[t]{2}{*}{ State Lower Ct } & -0.0313 & & 0.310 & & Atty General & 0.411 & 0.424 & $-1.809 *$ & \\
\hline & $(0.0168)$ & & $(0.584)$ & & & $(0.262)$ & $(0.267)$ & $(0.831)$ & \\
\hline \multirow[t]{2}{*}{ State Supr Court } & -0.0185 & -0.0244 & -0.207 & & Asst Dist Atty & -0.0113 & & -0.615 & -0.717 \\
\hline & $(0.0293)$ & $(0.0285)$ & $(1.053)$ & & & $(0.0204)$ & & $(0.702)$ & $(0.652)$ \\
\hline \multirow[t]{2}{*}{ State House } & -0.00906 & -0.00554 & 1.541 & 1.648 & Any Govt Exper & $0.0557 * *$ & $0.0416 * *$ & 0.952 & \\
\hline & $(0.0226)$ & $(0.0219)$ & $(1.077)$ & $(1.073)$ & & $(0.0176)$ & $(0.0147)$ & $(1.026)$ & \\
\hline \multirow[t]{2}{*}{ Solicit Gen Office } & 0 & & 0 & & Black & 0.0479 & 0.0423 & 0.525 & 1.038 \\
\hline & (.) & & $()$. & & & $(0.0339)$ & $(0.0318)$ & $(1.078)$ & $(1.012)$ \\
\hline \multirow[t]{2}{*}{ Solicitor General } & -0.0555 & & $6.385 * *$ & $6.424 * *$ & Cohort: 1910s & $0.0844 * *$ & $0.0776 * *$ & -5.369 & $-7.247 * *$ \\
\hline & $(0.109)$ & & $(0.811)$ & $(0.465)$ & & $(0.0149)$ & $(0.0152)$ & $(4.080)$ & $(0.644)$ \\
\hline \multirow[t]{2}{*}{ U.S. Senator } & -0.0547 & -0.0430 & 0 & & Cohort: 1920s & $0.245 * *$ & $0.236 * *$ & -2.129 & $-3.947 * *$ \\
\hline & $(0.0327)$ & $(0.0263)$ & $()$. & & & $(0.0247)$ & $(0.0246)$ & $(4.107)$ & $(0.685)$ \\
\hline \multirow[t]{2}{*}{ State Atty General } & -0.0397 & -0.0395 & -1.480 & -1.752 & Cohort: 1930s & $0.271 * *$ & $0.260 * *$ & 2.011 & \\
\hline & $(0.0235)$ & $(0.0237)$ & $(1.056)$ & (1.049) & & $(0.0269)$ & $(0.0266)$ & $(4.116)$ & \\
\hline \multirow[t]{2}{*}{ Private Practice } & 0.00725 & & 0.122 & & Cohort: 1940s & $0.126 * *$ & $0.114 * *$ & 6.373 & $4.518^{* *}$ \\
\hline & $(0.0276)$ & & $(1.177)$ & & & $(0.0200)$ & $(0.0187)$ & $(4.118)$ & $(0.768)$ \\
\hline \multirow[t]{2}{*}{ Mayor } & -0.0211 & -0.0251 & -1.125 & & Cohort: 1950 s & 0.0277 & & $9.056 *$ & $7.536 * *$ \\
\hline & $(0.0278)$ & $(0.0290)$ & $(1.360)$ & & & $(0.0149)$ & & $(4.291)$ & $(1.307)$ \\
\hline \multirow[t]{2}{*}{ Local Court } & 0.0353 & 0.0272 & 0.221 & & Bnktcy Judge & -0.0371 & & -0.420 & \\
\hline & $(0.0256)$ & $(0.0253)$ & $(0.780)$ & & & $(0.0540)$ & & $(2.678)$ & \\
\hline \multirow[t]{2}{*}{ U.S. House } & $-0.0488 * *$ & $-0.0447 * *$ & 0 & & Magistr Judge & $-0.0660 *$ & -0.0492 & 0.772 & 1.069 \\
\hline & $(0.0145)$ & $(0.0137)$ & $()$. & & & $(0.0287)$ & $(0.0254)$ & $(1.378)$ & $(1.405)$ \\
\hline All Variables & $x$ & & $x$ & & & $x$ & & $x$ & \\
\hline Post Elastic Net & & $x$ & & $x$ & & & $x$ & & $x$ \\
\hline $\mathrm{N}$ & 2226 & 2276 & 350 & 350 & & 2226 & 2276 & 350 & 350 \\
\hline adj. R-sq & 0.113 & 0.117 & 0.457 & 0.468 & & 0.113 & 0.117 & 0.457 & 0.468 \\
\hline
\end{tabular}

Notes. Regression of Manne training on all covariates (1) and (3) and elastic-net-selected covariates (2) and (4). Robust standard errors clustered at the judge level in parentheses. $* p<0.05, * * p<.01$. Data collapsed by judge. A variable that mentions a position means the judge had prior experience in that position. Codebook for variables available in online appendix. 
The perception put forward by the program from its annual reports is a collection of photographs of judges diligently taking notes and receiving reading assignments. In contrast to the Washington Post, a New York Times reporter writes:

For three weeks, 19 Federal judges from around the country took a grueling, six-day-a-week course in economics.. With classes starting at 9 A.M. and sometimes ending at 10 P.M. or later, the judges received the equivalent of a full semester at the college level. ... From the beginning, the judges, some of them 60 years or over, behaved like students, deferring to their teachers. ${ }^{27}$

While the courses were later shortened from three weeks, they were never shorter than two weeks.

Butler (1999) includes quotations from the author and judges' reaction to the program. Butler wrote that academic attention to the role of economics in law

could actually be the most lasting contribution of the judges' program to the development of law and economics . . . As I always told the judges in my session-closing remarks, 'If you are doing your job right, there really should not be many different results in your cases. But you will have a better understanding of the law because of the insights economics offers, and that will help you be better judges."' (p. 321, emphasis added). ${ }^{28}$

So at least in principle, the program was billed as a non-partisan tool to help judges understand their decisions.

The seminar made a lasting impression. Circuit Judge Paul Michel wrote that "[it] helped to provide a principled basis for deciding close cases," while Circuit Judge E. Grady Jolly appreciated "a sound theoretical and rational structure for my decisions... the potential effects and foreseeable impact of imposing a duty." Justice Ruth Bader Ginsburg wrote: "the instruction was far more intense than the Florida sun. For lifting the veil on such mysteries as regression analyses, and for advancing both learning and

27"19 U.S. Judges Study Economics to Help Them in Work on Bench"

${ }^{28}$ However, we find that the program actually did lead to different results, consistent with the testimony of participants as well as LEC promotional materials. The 1982 LEC annual report writes: "For those interested in the impact of our programs, one sentence out of a recent letter from a distinguished U.S. Court of Appeals judge says it all. "In reviewing the cases I have sat upon in the last six months, I thought you might be interested to know that in fully 50 percent of them a portion of the case or the whole case turned on an issue I felt I was better able to decide because of my opportunity to study in your program". Who could ask for stronger testimony?" 
collegial relationships among federal judges across the country, my enduring appreciation."

A few more choice quotes:

District Judge David Carter: "I regard myself as a social progressive and all the economists in attendance, from my perspective, had Neanderthal views on race and social policy. The basic lesson I learned .. is that social good comes at a price, a social and economic cost. I had never thought that through before being exposed to Henry's teachings. .... [It] has led me to measure the cost of the social good being furthered against the gain to be achieved."

District Judge Anthony Alaimo: "There is a wide area of decision entrusted to us where the result can go either way, depending on how we view the evidence. That area is called 'judicial discretion.' This is the area that is most affected by these seminars .. as a result of what I have learned at these seminars, I have become a much better judge."

District Judge Thomas Griesa: "Henry and his LEC colleagues were of a conservative persuasion. .. the class wanted to express our gratitude on the final day. The person who rose to speak was Judge Hall from West Virginia, who was from the Fourth Circuit. Without doubt he was a Democrat going back to New Deal days. He was fervent in his appreciation."

Supreme Court Justice Ruth Bader Ginsburg complimented Manne:

"Cheers to Henry, innovator and dean nonpareil. As a student in two of his seminars, I can affirm that the instruction was far more intense than the Florida sun. For lifting the veil on such mysteries as regression analyses, and for advancing both learning and collegial relationships among federal judges across the country, my enduring appreciation." (Letter from Justice Ruth Bader Ginsburg, Supreme Court of the United States (Mar. 1, 1999))

"the courses I attended helped to provide a principled basis for deciding close cases." (Letter from Judge Paul R. Michel, U.S. Court of Appeals for the Federal Circuit, to Henry N. Butler, Director, Law and Organizational Economics Center, University of Kansas 1-2 (Feb. 25, 1999))

"As a new judge, a principle concern for me was that I develop reasoned criteria for deciding cases. While each judge must wrestle with what that 
criteria should be, I found Henry's courses helped to provide me with a sound theoretical and rational structure for my decisions..."

[I]n many cases, one need look no further than the letter of the law. However, in those cases where the law is not clear, there is, consciously or unconsciously, a proclivity to resolve the case in favor of the party with whom you most identify or sympathize. To avoid succumbing to this pattern, it is essential to understand the economic and social impact of one's decision...

[T] he courses gave to me a greater understanding of the potential effects and foreseeable impact of imposing a duty or liability on a particular party in a case. And with that understanding came an appreciation of the broader impact that my decisions could have on other similarly situated parties. In sum, the courses I attended helped to provide a principled basis for deciding close cases." (Letter from Judge E. Grady Jolly, U.S. Court of Appeals for the Fifth Circuit, to Henry N. Butler, Director, Law and Organizational Economics Center, University of Kansas 1-2 (Feb. 17, 1999))

The programs were intense.

"Henry always chose places for classes that embodied the principles of economic success. One need only to look out the window to see it all around. One's eyes never wandered far as the teachers were always the epitome of expertise. However, Henry, as truly economic, made it clear that he expected one not to participate in the abundance that surrounded them until all the classes were over and done with." (Letter from Judge Robert G. Doumar, U.S. District Court for the Eastern District of Virginia, to Henry N. Butler, Director, Law and Organizational Economics Center, University of Kansas (Feb. 26, 1999))

"Frankly, I did not expect such a concentrated agenda. I don't believe I have ever attended a seminar that involved such intensive study and discussion. My wife, who accompanied me, commented, "I don't see any more of you here than I do at home." Another compliment came from one of my fellow judges who said, "I can't believe how much I have learned, but I'm glad I didn't have to take this course in college."' (Letter from Judge Thomas J. Curran, U.S. District Court for the Eastern District of Wisconsin, to Henry 
N. Butler, Director, Law and Organizational Economics Center, University of Kansas (Mar. 2, 1999))

Most importantly, from the perspective of criminal sentencing, is a self-identified social progressive who was led to measure decisions through costs and benefits, the potential scope of impact outside of traditional economic topics but to areas of "judicial discretion" more broadly, and the impact on non-conservatives:

"I attended the first of the law and economics programs Henry organized for federal judges and what was learned was so worthwhile that I attended two additional programs-this despite the fact that I regard myself as a social progressive and all the economists in attendance, from my perspective, had Neanderthal views on race and social policy. The basic lesson I learned, however, would have been forthcoming whatever the social outlook of the economist and that is that social good comes at a price, a social and economic cost. I had never thought that through before being exposed to Henry's teachings. While my views have not changed, the exposure to the thinking and teaching of the economists in these programs has led me to measure the cost of the social good being furthered against the gain to be achieved. I suppose what was learned amounts to social responsibility and required me to choose my priorities with greater care than before." (Letter from Judge Robert L. Carter, U.S. District Court for the Southern District of New York, to Henry N. Butler, Director, Law and Organizational Economics Center, University of Kansas 1-2 (Feb. 17, 1999))

"While we are circumscribed by the parameters of existing statutes, regulations and case law, there is a wide area of decision entrusted to us where the result can go either way, depending on how we view the evidence. That area is called "judicial discretion." This is the area that is most affected by these seminars on economics conducted under Dr. Manne's direction. I have attended his seminars during the past ten years and am eager to testify to their value. Indeed, I feel that, as a result of what I have learned at these seminars, I have become a much better judge, hopefully rendering more valuable and salutary decisions to this society." (Letter from Judge Anthony A. Alaimo, U.S. District Court for the Southern District of Georgia, to William E. Simon, President, The John M. Olin Foundation, Inc., 2-3 (June 20, 1989)) 
Table 17: Randomization Check: Manne Judges Don’t See More Econ Cases

\begin{tabular}{lcccc}
\hline & \multicolumn{4}{c}{ Economics Case } \\
& $(1)$ & $(2)$ & $(3)$ & $(4)$ \\
\hline Econ Training & 0.00788 & -0.000716 & -0.00512 & 0.00540 \\
& $(0.00807)$ & $(0.00454)$ & $(0.00893)$ & $(0.00416)$ \\
\hline $\mathrm{N}$ & 123519 & 115561 & 500266 & 389105 \\
adj. R-sq & 0.115 & 0.024 & 0.112 & 0.023 \\
\hline Circuit-Year FE & $\mathrm{Y}$ & $\mathrm{Y}$ & $\mathrm{Y}$ & $\mathrm{Y}$ \\
Sample & Author & Author & On Panel & On Panel \\
Sample & Year $<1976$ & Year $>1991$ & Year $<1976$ & Year $>1991$ \\
Notes & Regression coefficients from regression proportion economics case on a dummy for Manne training and a circuit- \\
year fixed effect. (1) and (2) limit to the authoring judge. (1) and (3) are a placebo effect for before the start of the \\
program. Observations are weighted to treat judge-years equally.
\end{tabular}

"There has been a feeling in some quarters that Henry and his LEC colleagues were of a conservative persuasion. I am not inclined to deny that. However, what has been taught has been professional economics of the highest and most sophisticated caliber. In any event, people of all stripes have attended and greatly benefited. I recall my first course when the class wanted to express our gratitude on the final day. The person who rose to speak was Judge Hall from West Virginia, who was from the Fourth Circuit. Without doubt he was a Democrat going back to New Deal days. He was fervent in his appreciation of the LEC course." (Letter from Judge Thomas P. Griesa, U.S. District Court for the Southern District of New York, to Henry N. Butler, Director, Law and Organizational Economics Center, University of Kansas 2 (Mar. 30, 1999))

Consistent with potential impact on judicial discretion, the Manne Judges effect appears solely with the post-Booker period, after United States v. Booker loosened the formerly mandatory U.S. Sentencing Guidelines.

\section{Judge Randomization Checks}

Table 17 shows that randomness does not appear to be violated in the context of Manne judges and the proportion of cases published on economics topics. In addition, they do not selectively author more economics cases.

Table 18 presents an omnibus check for endogenous settlement or selection of cases 
Table 18: Randomization Check: Manne District Judges Don't Receive Different Types of Crime Cases

\begin{tabular}{lccccc}
\hline & & \multicolumn{3}{c}{ Econ Training } & \\
\cline { 5 - 6 } & $(1)$ & $(2)$ & $(3)$ & $(4)$ & $(5)$ \\
\hline Crime Type & -0.00545 & 0.0148 & -0.00362 & 0.00319 & -0.000646 \\
& $(0.0157)$ & $(0.0441)$ & $(0.0107)$ & $(0.00898)$ & $(0.00939)$ \\
Crime Type * & 0.0127 & -0.0132 & -0.00621 & -0.00825 & -0.00691 \\
Booker $(\geq 2005)$ & $(0.0127)$ & $(0.0445)$ & $(0.0160)$ & $(0.0147)$ & $(0.0142)$ \\
N & 930448 & 930448 & 930448 & 930448 & 930448 \\
adj. R-sq & 0.245 & 0.245 & 0.245 & 0.245 & 0.245 \\
\hline Courthouse and Calendar FE & Y & Y & Y & Y & Y \\
Crime Type & Drug & Immigration & Fraud & Weapon & Other \\
\hline
\end{tabular}

Effect of Manne Econ Training on the type of cases taken by district court judges.

by judges. It shows that economics judges are not systematically appearing on certain types of crimes before or after Booker.

\section{Language Effect Placebos}

Figure 12 provides a placebo test for the event-study impact of Manne program on language. We show in the left panel that similarity to (non-economics) academic legal writing does not change discretely at the time of attendance. In the right panel, another measure of movement conservatism (originalism, measured by citation to bill of rights amendments), also does not change discretely at the time of attendance.

In Table 19, we show that Manne attendance does not affect the probability that a judge cites Reagan or Bush nominees, meaning that it is not driven by conservatism generally.

\section{E Manne Training and Racial and Gender Disparities in Criminal Sentencing}

Table 20 presents an analysis of the impact of economics judges on racial gaps. The first row shows that minority defendants were treated systematically harsher, more frequently assigned in the upper half of the sentencing guidelines, more frequently receiving life in prison, and having more months of sentence lengths. The second row 
Figure 12: Manne Attendance, Law-Journal Similarity, and Originalism
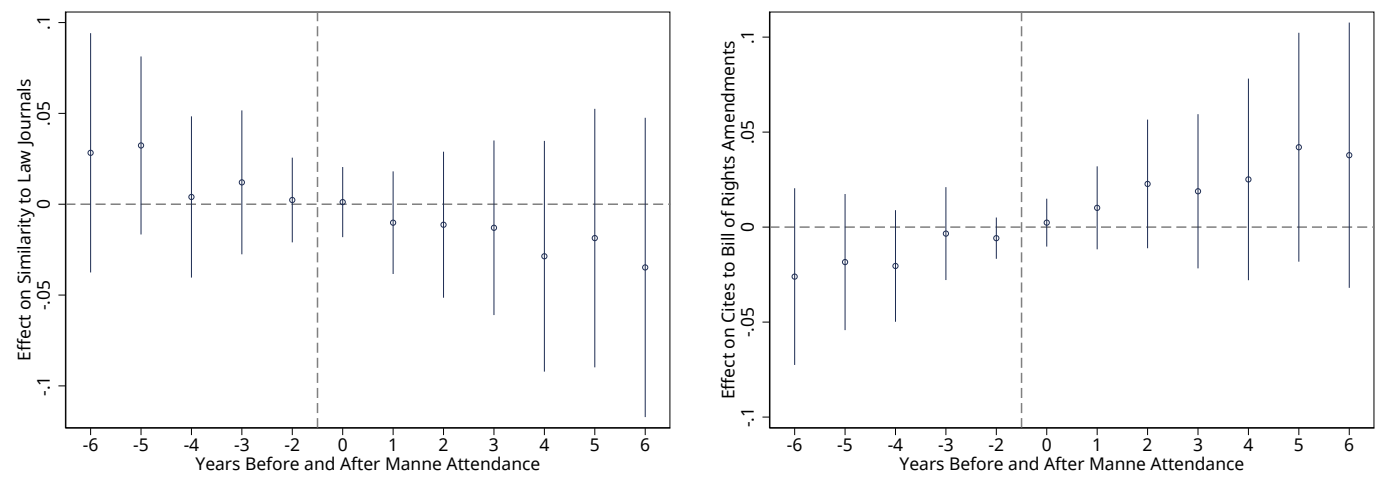

Notes. Average similarity to law journals (left panel), and citation rate to Bill of Rights amendments (right panel) of Manne judges, for years before and after Manne attendance. Event study regressions include judge and circuit-year fixed effects. Error spikes give $95 \%$ confidence intervals. Limited to economcs cases and case authors

Table 19: Effect of Manne Attendance on Citations to Reagan/Bush Appointees

Case Cites Reagan/Bush Nominee

$\begin{array}{ccccc}\text { Econ Training X Post Manne } & 0.0000452 & 0.000486 & 0.00180 & 0.00109 \\ (0.00261) & (0.00259) & (0.00360) & (0.00361)\end{array}$

\begin{tabular}{lcccc}
\hline N & 886988 & 886988 & 886988 & 886988 \\
adj. R-sq. & 0.149 & 0.150 & 0.150 & 0.150 \\
\hline Circuit-Year FE & $\mathrm{X}$ & $\mathrm{X}$ & $\mathrm{X}$ & $\mathrm{X}$ \\
Judge FE & $\mathrm{X}$ & $\mathrm{X}$ & $\mathrm{X}$ & $\mathrm{X}$ \\
Party $\times$ Year FE & & $\mathrm{X}$ & $\mathrm{X}$ & $\mathrm{X}$ \\
Ever-Attend $\times$ Year FE & & & $\mathrm{X}$ & $\mathrm{X}$ \\
E-net-Vars $\times$ Year FE & & & & $\mathrm{X}$
\end{tabular}

Notes. Effect of Manne economics training on citing Reagan or Bush Supreme Court nominees. Standard errors clustered by judge. Observations are weighted to treat judge-years equally. $+p<.1, * p<0.05, * * p<.01$. Includes years 1970 through 2005. 
indicates that economics judges exacerbate this gap, sometimes substantially (doubling the gap for life imprisonment). The expressive effects weaken with the inclusion of the Republican interaction and whether the judge is also a racial minority. However the substantive gaps remain stable and, in terms of life imprisonment, more strongly predictive by economics training than by Republican party of appointment. The final row shows some evidence of racial in-group bias, though bias by whom is unknown without a benchmark.

Table 21 presents an analysis of the impact of economics judges on gender gaps. The first row shows that female defendants were treated systematically more leniently, more frequently assigned in the lower half of the sentencing guidelines, less frequently receiving life in prison, and having fewer months in sentence lengths. The second row indicates that economics judges exacerbate this gap, sometimes substantially (doubling the gap for life imprisonment). The expressive and substantive effects are robust to the inclusion of the Republican interaction and whether the judge is female. Note that economics training is more predictive of these gaps than Republican party of appointment. These results are consistent with the use of stereotypes under information constraints (Bordalo et al. 2016) where the representative heuristic overweights and distorts beliefs. An earlier line of work in information theory (Cover and Thomas 1991) also suggests that information constraints result in exaggerating pre-existing correlations.

\section{F Memetic Diffusion of Particular Phrases}

Table 22 presents the regression (controlling for whether the previous case in the Circuit had an Economics Trained judge). The words "capital" and "deterrence" and the phrase "law and economics" tend to travel within a judge. To explain: For every 100 cases, an economics trained judge will use "capital" in 5 cases (Column 2). If a judge's previous case was with a Manne judge, the judge will use "capital" in 7 out of 100 cases (Column 3 ). If the future case is assigned with a Manne judge, there is no difference from baseline (Column 1).

The same holds with "deterrence." For every 100 cases, a Manne judge writes "deterrence" in 1.6 cases (Column 6). If a judge sat with an Manne judge in his or her previous case, the judge will use "deterrence" in 1.3 cases out of 100 cases (Column 7). This effect carries into two cases later (Column 8). Again, the lead effect is small and insignificant with standard errors close to the treatment effects (Column 5). 


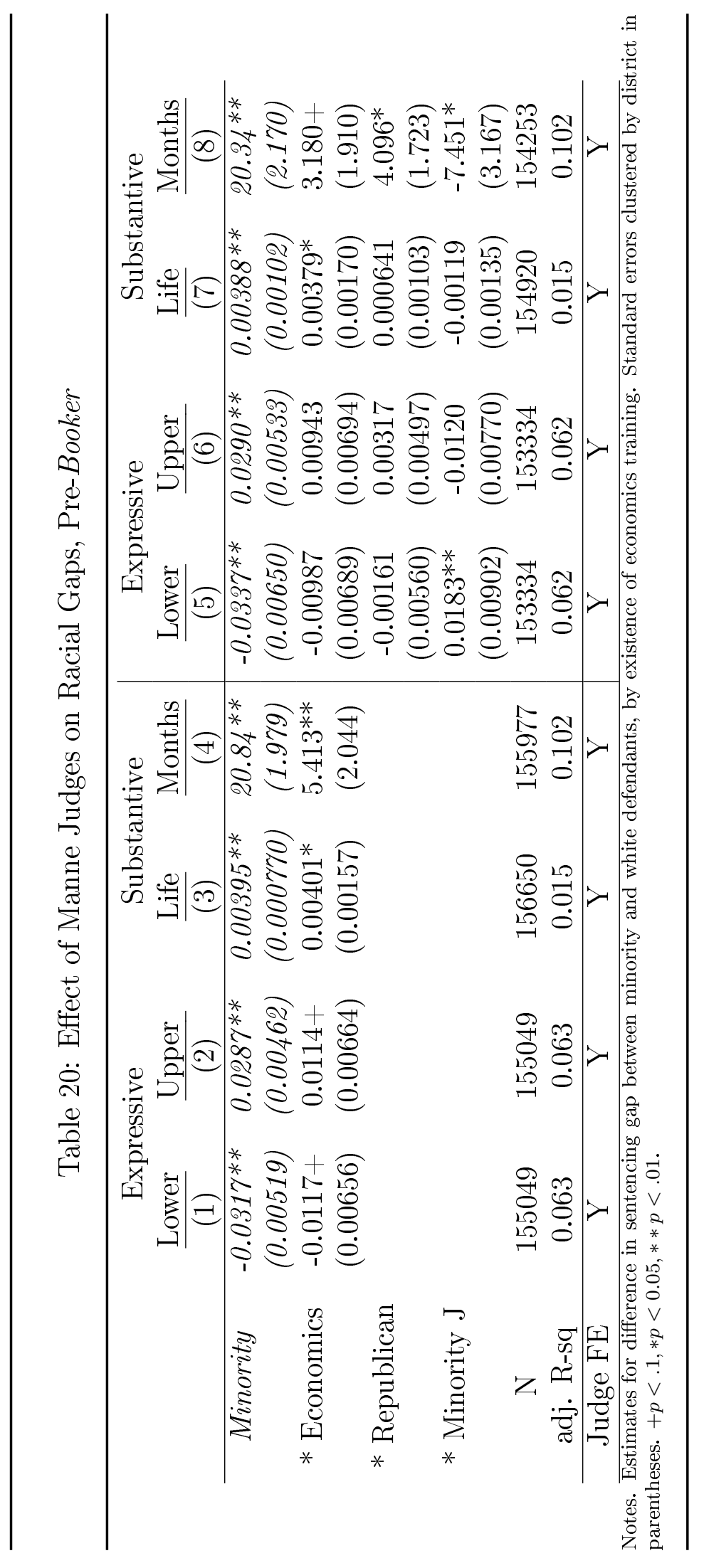




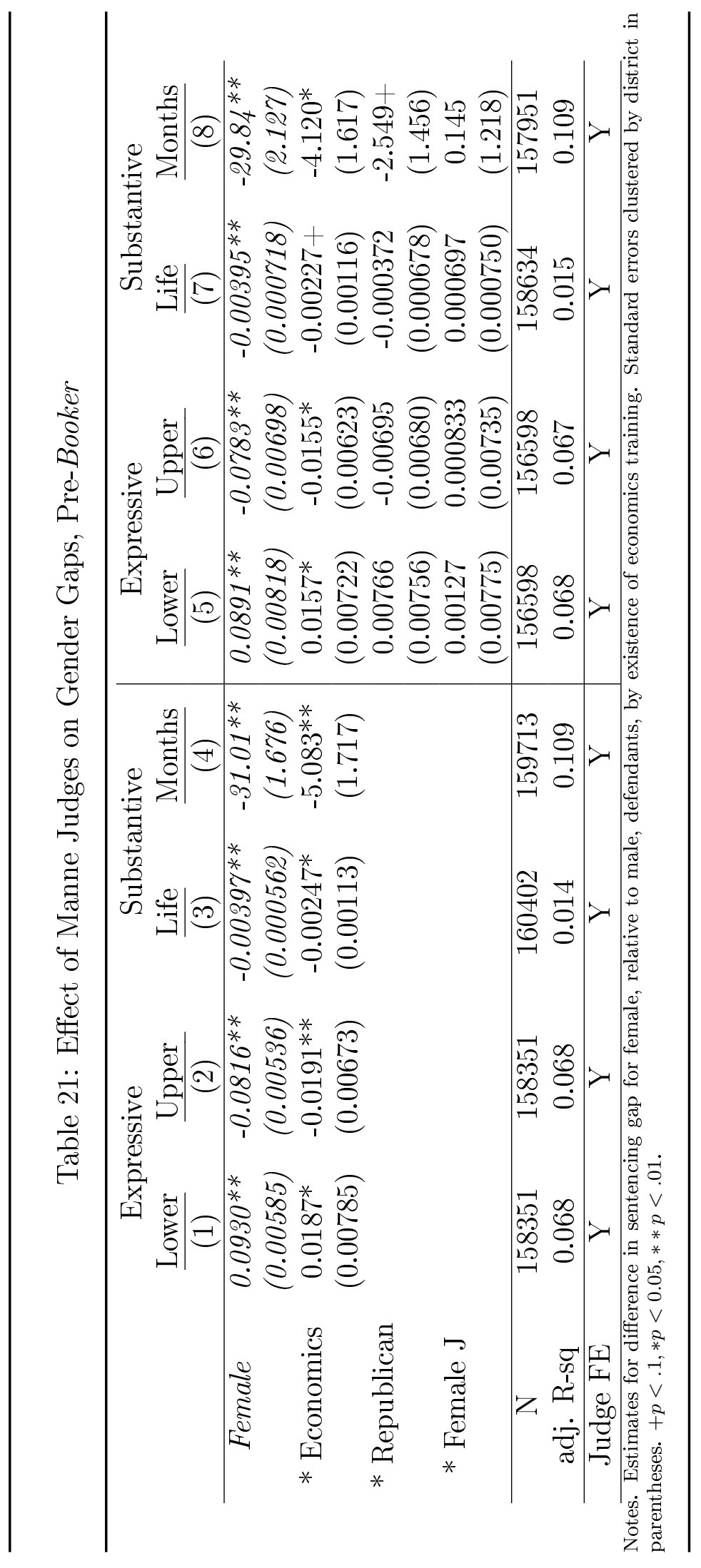


Finally, in the bottom panel, we see a similar pattern for "law and economics." For every 2000 cases, 1 case will include "law and economics" when an economics-trained judge is on the case (Column 10). If the previous case of the judge had an economicstrained judge, the same 1 out of 200 effect is observed (Column 11), and again two cases later (Col 12). Importantly, no effect is found for the case in advance of being assigned with an economics trained judge (Column 9). In general, the results are persistent with some decay. We find certain words, like "deterrence," transmit at least 4 cases after exposure. Note that 4 cases in the past is an average of 43 days in the past, which would reflect relatively persistent learning effects. 
Table 22: Identifying Memetic Economics Phrases

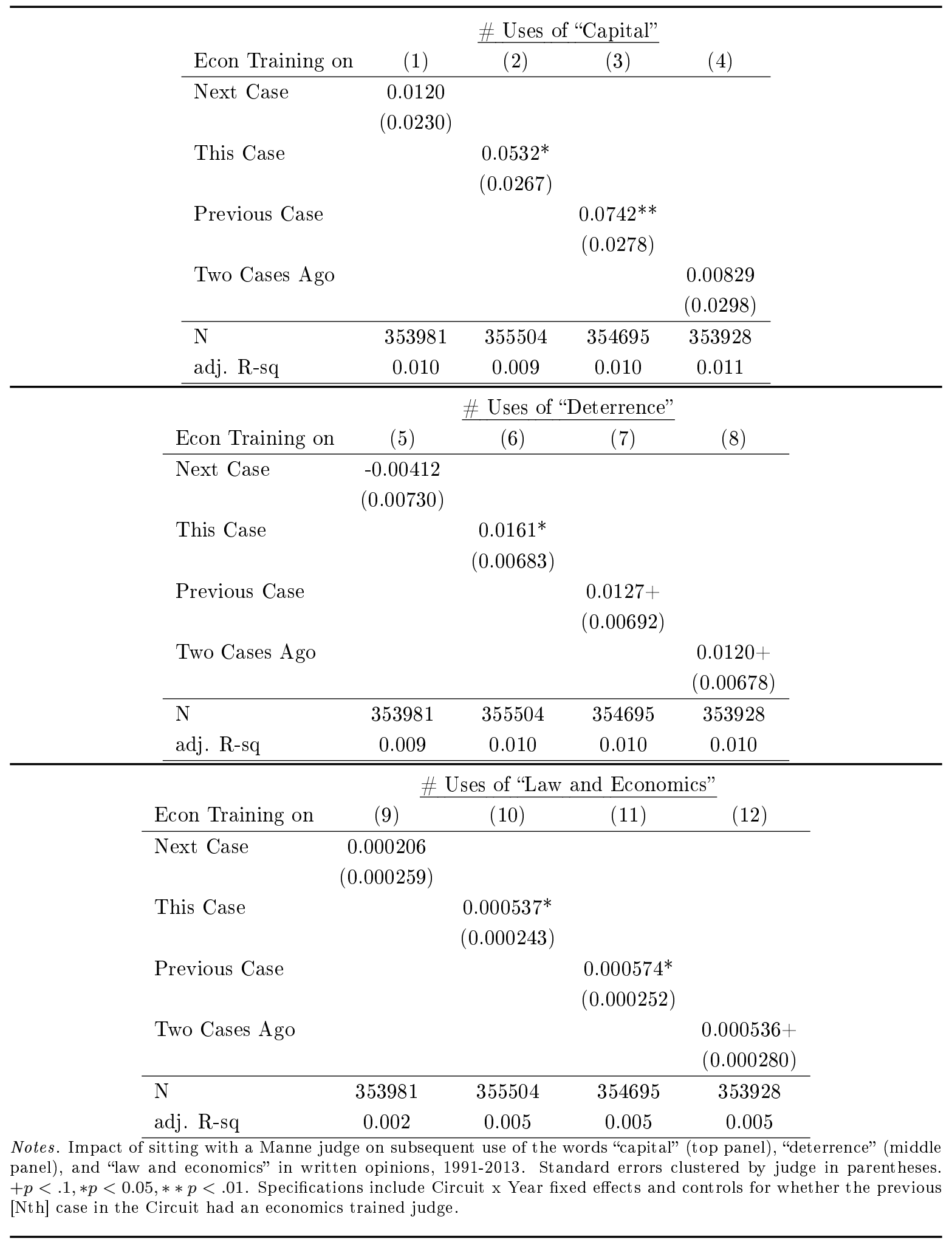

